\title{
Středověká kožedělná produkce z Litovle
}

Medieval leather production from Litovel

- Aleš Hoch, Pavel Šlézar* -

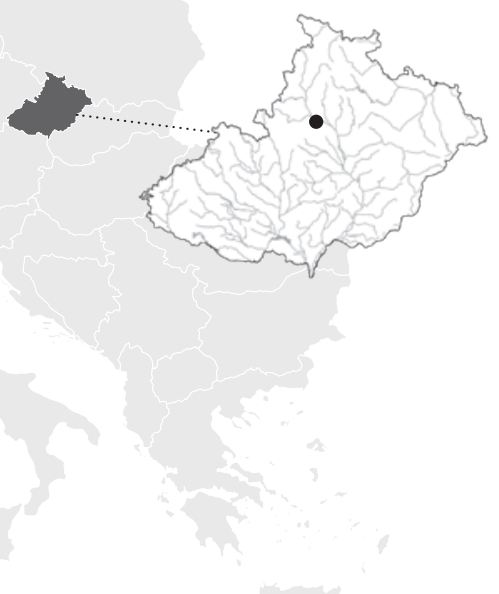

\section{KEYWORDS}

Litovel - High Middle Ages - leather artefacts - town - leather production

\section{ABSTRACT}

Between 1997 and 2017, an extensive collection of approximately 3,500 leather fragments from the second half of the 13th to the 15th century was obtained from archaeological rescue excavations carried out in the historic core of Litovel. Most of the finds come from public areas of the town. Only a few dozen artefacts have been determined in terms of their original function. All the remaining finds can be classified as primary to secondary waste, among which manufacturing waste was often present, indicating the nearby presence of a craft workshop. In the case of Litovel, this has been demonstrated at two sites, and hypothetically at three others. These are specifically shoemaker or cobbler workshops. The leather artefact assemblage from $L i^{-}$ tovel contains typical representatives of material culture from the High and Late Middle Ages, most often in the form of shoes (high and low cuts, children's sizes), clothing accessories (belts), equipment (scabbards) and items rarely found elsewhere including unique objects such as a case for wax writing tablets and a face mask.

\footnotetext{
*Corresponding author - E-mail address: slezar.pavel@npu.cz

https://doi.org/10.47382/pv0622-05
}

Received 6 October 2021; received in revised form 26 November 2021. Available online 30 December 2021

Copyright (c) 2021 Czech Acad Sci, Inst Archaeology Brno, and the authors.

This is an open access article under the CC BY-NC-ND 4.0 license

(https://creativecommons.org/licenses/by-nc-nd/4.0/).

Competing interests: The authors have declared that no competing interests exist.

\section{1. Úvod}

Bývalé královské město Litovel, ležící v severozápadní části Hornomoravského úvalu, patř́i k archeologicky nejlépe prozkoumaným moravským městům. Proces archeologického poznávání Litovelska sahá svou tradicí již do počátku 19. století. K největšímu rozvoji systematické záchrany ohrožených archeologických pramenů došlo po katastrofálních záplavách v roce 1997 v souvislosti s následnou obnovou budov a další rozvíjející se stavební činností (Faltýnek, Šlézar 2006, 303-304; Kalábková 2018). Do současnosti byla v Litovli realizována desítka větších a na sedm desítek menších archeologických akcí, které jsou podrobně evidovány prostřednictvím informačního a mapového systému Archeologický atlas MPZ Litovel (Šlézar et al. 2018). Dosud nejrozsáhlejší výzkum proběhl při výstavbě kanalizace v roce 2003, která zasáhla přibližně $75 \%$ uliční sítě historického jádra města (Šlézar, Faltýnek 2004, 204).

V 50. letech 13. století bylo osídlení přeloženo z předlokačního sídliště s centrální a trhovou funkcí (trhová ves) na litovelském Starém městě do prostoru současného historického jádra města Litovle, ležícího v rozvětveném systému ramen řeky Moravy. Litovel jako typické „město na řece“, nazývané také „hanácké Benátky“, mělo celou řadu specifických rysů ve vztahu k prŕrodnímu prostředí, z nichž mnohé zachytily archeologické výzkumy. Časté byly úpravy terénu a hydrologických poměrů jako mýcení stromů, odvodňování, úprava toku ramen Moravy, zpevnění nestabilního povrchu pomocí dubových pilotů, dorovnání drobných terénních nepravidelností, hatování cest a budování dřevěných mostů. Vysoká hladina spodní vody si vyžádala budování melioračních kanálů a trativodů, často stavěných ze dřeva. Snaha o nárůst terénu jako ochrany proti povodním vedla ve 2 . polovině 13 . až 15 . století k ukládání mohutných vrstev organogenního odpadu (i více než $3 \mathrm{~m}$ ), prokládaných izolačními vrstvami jílů, dřevěnými hatěmi, primitivním dlážděním pomocí oblázkových posypů i kamennými dlažbami na veřejných plochách. Zvýšení úrovně povrchu terénu historického jádra Litovle se pozitivně projevilo při katastrofálních záplavách v roce 1997, kdy historické jádro města nebylo zaplaveno, i když nivelety podloží zde neprokazují existenci žádné přirozené vyvýšeniny. Terén vinou vysoké hladiny spodní vody nedovoloval ani výrazné zahlubování staveb, to se objevuje až v pozdním středověku, a to již do vrstev vzniklých antropogenní činností. O specifickém zacházení s odpadem v Litovli svědčí i skutečnost, že z města prozatím postrádáme nálezy středověkých odpadních jímek. Zvodnělé prostředí středověkých vrstev veřejných ploch i městských parcel Litovle výjimečně dobře uchovává archeologické artefakty z organických materiálů jako je kůže, dřevo, provazy, které se jinak zachovávají zejména ve specifických 
archeologických situacích (jímky, studny). Dochované díly dřevěných konstrukcí navíc umožňují archeologické situace v Litovli dobře datovat pomocí dendrochronologie (Faltýnek, Šlézar 2016; Šlézar 2018a, 79, 82-83; 2018b, 256-257, 259, 263-264; Faltýnek 2019, 131).

Cílem předložené studie je vyhodnocení velmi hodnotného souboru kožených artefaktů, které se v antropogenních uloženinách městského jádra dochovaly, a to v širším soudobém kontextu.

Litovelská městská kniha z let 1359-1577 nám bohužel nepřináší mnoho svědectví o kožedělné výrobě ve městě, nicméně již v roce 1364 je zmiňován člen městské rady švec Blažej (srov. Bezděčka 1993, 57; Lošták 1976). V rychtářské knize z let 1586-1594 je v Litovli uvedeno 10 ševců. Rektifikační akta z roku 1749 udávají ve městě 22 ševců, 6 koželuhů a jednoho řemenáře a pasíře, kteří jsou jmenovitě vypsáni, ale bez konkrétních lokací. Z roku 1601 pochází rozsáhlé artikule ševcovského cechu v Litovli o 28 článcích. Řemeslníci se dělili na obuvníky a př́úštipkáře. Velice přísně se kontrolovala kvalita obuvi, nekvalitní výrobky byly opraveny nebo dány chudým. Pokutována byla např̀ výroba obuvi z koňské nebo vepřové kůže (Bezděčka 1993, 136; Grolich 1971, 3, 8-11, 45-48).

\section{Metoda zpracování}

Nálezový soubor pochází z třinácti lokalit z městského historického jádra Litovle a čítá dohromady více než 3500 artefaktů. Přesný počet není možné určit, nebot̉ je značná část v silně fragmentárním stavu. Z hlediska původní funkce bylo determinováno pouze několik desítek artefaktů, avšak přiřadit ke konkrétním typům byl možný pouze naprostý zlomek. Veškeré zbylé předměty můžeme označit za primární až sekundární odpad, mezi kterým se velice často vyskytl i odpad z výroby, indikující blízkou přítomnost dílny. Všechny artefakty byly nejprve rozděleny dle místa nálezu, a dále dle soudobé metodiky do funkčních skupin (obuv, pochvy a pouzdra, opasky a řemeny, rukavice, varia). Vybrané předměty s největší vypovídací hodnotou byly zařazeny do katalogu a detailně popsány (obr. 1).

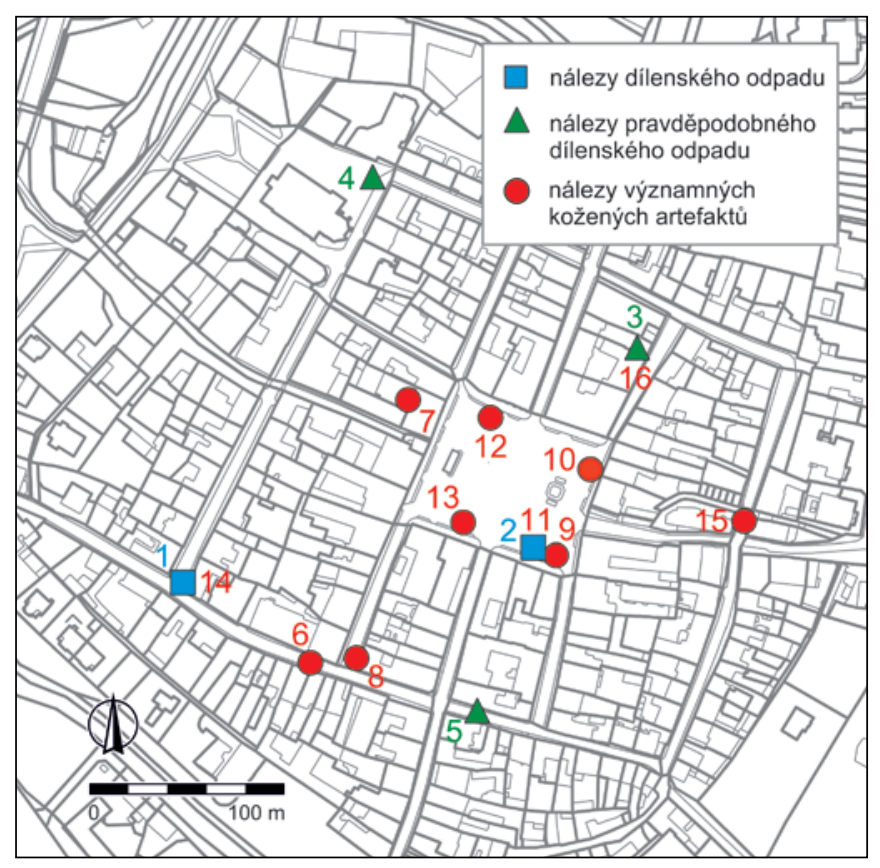

\section{Charakteristika souborů usní a jejich nálezové okolnosti}

\subsection{Boskovicova ulice (akce č. PU02/01; akce č. NPU015/03-391, sonda S19/03)}

\section{Nálezové situace}

a) V roce 2001 byl dokumentován a vzorkován 53 m dlouhý a 0,7 m široký výkop kanalizace. Výkop dosáhl hloubky $1,65 \mathrm{~m}$, aniž by bylo dosaženo intaktního geologického podloží. Nejstarší zkoumané kulturní vrstvy pocházely z období 1. poloviny 14. století. Kromě standardní datace pomocí keramiky je chronologické zařazení nejstarších zkoumaných kulturních vrstev podpořeno i dendrochronologií. Vzorek dřevěné kulatiny byl datován do roku 1340 (Vrbová 2001, 4-5). Organogenní souvrství se kontinuálně utvářelo až do průběhu 16. století (Faltýnek 2002). Usňové dílce pochází z vrstev datovaných do rozmezí 2 . poloviny 14 . století až 15 . století.

b) Sonda S19/03 o rozměrech 5,2 × 1,2 m byla vyhloubena během výstavby kanalizace v roce 2003 na Boskovicově ulici při nároží s ulicí Havlíčkovou. Geologické podloží leželo 3,2 m pod současným povrchem. Do podloží byl zahlouben odvodňovací kanál o šířce $0,8 \mathrm{~m}$ a hloubce $0,5 \mathrm{~m}$ z doby lokace města, sledovaný v délce $3 \mathrm{~m}$. Organogenní odpadní uliční souvrství o celkové mocnosti $2,5 \mathrm{~m}$ bylo prokládané jednoduchými dlážděními z posypů říčních oblázků a jílových izolačních vrstev. Z této sekvence, utvářené v průběhu 2. poloviny 13. až 15. století, pochází nálezy usňových dílců. V jižní partii sondy byla objevena kamenná studna z 2 . poloviny 14 . století o vnitřním průměru $1,45 \mathrm{~m}$ a hloubce $5,6 \mathrm{~m}$. Po nárůstu okolního terénu byla studna v 15 . století nadstavěna nekvalitním kamenným pláštěm. Charakter a výplň zásypu svědčily, že studna fungovala ještě na přelomu 19. a 20. století (Šlézar, Faltýnek 2004, 205-206).

\section{Charakteristika souboru usní}

V první skupině předmětů dominují neidentifikovatelné nálezy v počtu přibližně 170 kusů, klasifikovatelné jako primární či sekundární odpad. Z určitelných nálezů vyniká nekompletní půlpár dětské obuvi a část prosekávaného opasku z vrstev 2. poloviny 13. století.

Obr. 1. Nálezy usní z Litovle z 2. poloviny 13. až 15. století. 1 - Komenského ulice, sonda S24/03; 2 - náměstí Přemysla Otakara, situace XVI/2; 3 - Masarykova ulice, sonda S1/17; 4 - Revoluční ulice, sonda S21/03; 5 - Havlí̌kova ulice, situace XVIII/1; 6 - Havlíčkova ulice, situace XXXVI/1-2: svršek boty (nízký střevíc); 7 - náměstí Přemysla Otakara, sonda S1/16: část dětského pưlpáru knoflíkové obuvi; 8 - Boskovicova ulice, S19/03: polovina dětského půlpáru knoflíkové obuvi a opasek; 9 - náměstí Přemysla Otakara, sonda S3/03: obuv „slip on shoe“; 10 - náměstí Přemysla Otakara, sonda S4/03: pouzdro na voskové destičky; 11 - náměstí Přemysla Otakara, situace XVI/2: opasky; 12 - náměstí Přemysla Otakara, sonda S15/03: opasek/pochva; 13 - náměstí Přemysla Otakara, sonda S10/03: pochva, nártová část svršku obuvi; 14 - Komenského ulice, sonda S24/03: rukavice; 15 - Jungmannova ulice, situace V: ,maska“; 16 - Masarykova ulice, sonda S1/17: svršek dětské boty (s dvojitou podešví). Autoři A. Hoch, P. Šlézar, digitalizace J. Grégr.

Fig. 1. Leather finds from Litovel from the second half of the 13th to 15th century. 1 - Komenský Street, trench S24/03; 2 - Přemysl Otakar Square, context XVI/2; 3 - Masarykova Street, trench S1/17; 4 - Revoluční Street, trench S21/03; 5 - Havlíčkova Street, context XVIII/1; 6 - Havlíčkova Street, context XXXVI/1-2: shoe upper (low shoe); 7 - Přemysl Otakar Square, trench S1/16: a part of a child's button shoe; 8 - Boskovicova Street, trench S19/03: half of a child's button shoe and a belt; 9 - Přemysl Otakar Square, trench S3/03: a slip on shoe; 10 - Přemysl Otakar Square, trench S4/03: case for wax writing tablets; 11 - Přemysl Otakar Square, context XVI/2: belts; 12 - Přemysl Otakar Square, trench S15/03: belt/sheath; 13 - PřemysI Otakar Square, trench S10/03: sheath, upper part of shoe upper; 14 - Komenský Street, trench S24/03: gloves; 15 - Jungmannova Street, context V: “mask”; 16 - Masarykova Street, trench S1/17: upper part of a child's shoe (with double sole). Authors A. Hoch, P. Šlézar; digitization by J. Grégr. 


\subsection{Havlíčkova ulice (akce č. NPU015/03-391, situace $X V I I I / 1$, situace $X X X V I / 1-2$, situace $X X X V I / 3$ )}

\section{Nálezové situace}

V průběhu výstavby kanalizace v roce 2003 bylo na Havlíčkově ulici dokumentováno několik terénních situací s nálezy usňových dílců. Geologické podloží se v úseku mezi domy č. p. 703 až č. p. 699 pohybovalo od hloubky $2,8 \mathrm{~m}$ až 2,2 $\mathrm{m}$ a dále západním směrem dosahovalo hloubky $1,9 \mathrm{~m}$, přičemž niveleta podloží byla konstantní. Mocnost středověkých souvrství se tedy zmenšovala směrem k okraji města, což bylo potvrzeno i v jiných částech města. Středověké organogenní vrstvy, ze kterých pocházely nálezy usní, ležely v rozmezí hloubek 0,8 až $1,5 \mathrm{~m}$.

a) V př́padě situace XVIII/1 před č. p. 790 byla v tmavě šedé humózní vrstvě zachycena kumulace několika desítek fragmentů kůží, pravděpodobně odpadu $\mathrm{z}$ dílny $\mathrm{z}$ průběhu 15. století. Horní hranice vrstvy ležela pouhých $0,2 \mathrm{~m}$ pod současným povrchem. Charakter stavebních prací neumožnil detailnější dokumentaci vertikální stratigrafie.

b) Z úseku kanalizace na ulici mezi č. p. 703 až č. p. 700 (situace XXXVI/1-2) byl formou sběru $\mathrm{z}$ výkopku zeminy získán dílec obuvi.

c) Ze situace XXXVI/3 z ulice před č. p. 699 byl získán menší soubor fragmentů kůží z organogenních vrstev datovaných do rozmezí 2 . poloviny 13 . až 15 . století. $\mathrm{V}$ těchto místech geologické podloží leželo v hloubce $2,2 \mathrm{~m}$ a středověké organogenní uloženiny se nacházely od úrovně $0,8 \mathrm{~m}$ pod povrchem. Charakter stavebních prací neumožnil detailnější dokumentaci vertikální stratigrafie.

\section{Charakteristika souboru}

Z této ulice (situace XXXVI/1-2) pochází nejzachovalejší dílec obuvi z celého souboru. Jedná se o nízce stř̌ižený svršek $\mathrm{s}$ výrazněji vykrojeným nártem a upínáním přes něj pomocí úzkých zavazovacích řemínků. Také ve zbytku zdejšího souboru převládají části obuvi (svrškové dílce, části podešví, opatek) a zejména desítky jejich fragmentů.

\subsection{Husova ulice (akce č. NPU030/04-391, sonda S1/04)}

\section{Nálezová situace}

Na nárožní parcele č. 187 ulic Husovy a Jungmannovy byla $\mathrm{v}$ roce 2004 realizována zjištovací sonda $\mathrm{v}$ délce $18 \mathrm{~m}$ a šířce 1,5 m v souvislosti s plánovanou výstavbou rehabilitačního zarrízení. Podloží se nacházelo v hloubce 1,9 až $2 \mathrm{~m}$ pod povrchem. $\mathrm{Z}$ doby lokace města v polovině 13 . století pocházely organogenní vrstvy s odštěpky snad stavebního dřeva i fragmentů usní. V jižní polovině sondy byla zachycena struktura sloupových jamek a hliněná pec. $V$ průběhu 2. poloviny 13. století se v prostoru městiště vytvořily dvě funkčně odlišné části. V severní polovině sondy se nacházelo $1 \mathrm{~m}$ mocné souvrství čtyř horizontů destrukcí nadzemních dřevohliněných domů z průběhu 2. poloviny 13. až 15. století. V jižní polovině sondy fungovala nádvorní část parcely. Nad podložím se v této části parcely ukládaly organogenní vrstvy datované do 2 . poloviny 13 století, ze kterých pochází fragmenty kủží. U odpadních vrstev 14. století již organogenní komponenty uloženin nebyly převažující. Na rozhraní mezi obytným a odpadním dvorkovým areálem byla prozkoumána hliněná pec ze 14. století a druhá mladší pec z období novověku. Na jižním konci sondy při rozhraní se sousední parcelou byla prozkoumána odpadní jímka z 16. století (Šlézar 2005).

\section{Charakteristika souboru}

Přibližně 60 až 70 neidentifikovatelných útržků, úlomků a odřezků.

\subsection{Jungmannova ulice (akce č. NPU015/03-391, situace V, situace XXXIII)}

\section{Nálezové situace}

a) Ve spojitosti s výstavbou kanalizace $\mathrm{v}$ roce 2003 byl před č. p. 653 v blízkosti křižovatky s Husovou ulicí dokumentován výkop o rozměrech $2,9 \times 1,6 \mathrm{~m}$ (situace $\mathrm{V}$ ). Intaktní geologické podloží leželo $\mathrm{v}$ hloubce $1,95 \mathrm{~m}$ pod povrchem. Od hloubky 1,6 m se nacházela organogenní odpadní vrstva. Pod ní se od hloubky 1,9 m rozkládalo na podloží ležící dláždění ze 14. století, tvořené posypem z říčních oblázků. Z dláždění pochází nález zřejmě kožené obličejové masky.

b) Mezi domy č. p. 648 až 650 (situace XXXIII) bylo v ulici zachyceno geologické podloží v hloubkách 1,85 až $2,1 \mathrm{~m}$. Odpadní organogenní uloženiny se nacházely od úrovně $0,9 \mathrm{~m}$ pod povrchem a sahaly až na intaktní geologické podloží. Fragmenty kůží pochází z vrstev datovaných do 2. poloviny 13 až 14. století.

\section{Charakteristika souboru}

Několik dílců z obuvi (opatky, části podešví) a větší množství fragmentů dílců či jiného odpadu (kolem 70 předmětů) zcela zastiňuje nález velkého, nepravidelně vykrojeného dílce interpretovaného jako možná obličejová maska z vrstvy datované do 14. století.

\subsection{Komenského ulice (akce č. NPU015/03-391, sonda S24/03)}

\section{Nálezová situace}

Na Komenského ulici byla v blízkosti křižovatky s Havlíčkovou ulicí v souvislosti s výstavbou kanalizace provedena v roce 2003 sonda S24/03 o rozměrech $4 \times 1 \mathrm{~m}$. Do intaktního geologického podloží ležícího v hloubce $2,15 \mathrm{~m}$ pod povrchem se zahlubovala $0,5 \mathrm{~m}$ jáma neznámých rozměrů z 2 . poloviny 13 . století. Na počátku 14. století tudy ve směru sever-jih vedl odvodňovací kanál o šířce $1,1 \mathrm{~m}$ a hloubce $0,4 \mathrm{~m}$. Kanál byl vyztužený bočnicemi z fošen a doplněný kůlovou konstrukcí. Velké množství usní (dílenského odpadu) nalezených v organogenních uloženinách o mocnosti kolem $1 \mathrm{~m}$ a datovaných do průběhu 14. století svědčí o tom, že se tento prostor stal odpadním místem pro ševcovskou dílnu, pracující v bezprostředním okolí. Sled středověkých uloženin uzavíraly uliční vrstvy z 15. století, tentokrát již bez nálezů kůží (obr. 2). Novověké vrstvy byly tvořeny stavebním odpadem (Šlézar, Faltýnek 2004, 206).

\section{Charakteristika souboru}

Počtem největší kolekce artefaktů v souboru, čítající tisíce drobných odřezků z výroby a jiný odpad (např. recyklované usně), dokládá blízkou přítomnost ševcovské dílny, pravděpodobně ševce-vetešníka. Vetešníci směli primárně obuv pouze opravovat, nikoliv šít novou (cf. Winter 1906, 140-141; Čermák 2002, 164 aj.). Mezi určitelnými předměty zaujme 14 kusů různých opravných dílců podešví či záplat svršků, dětská podešev a zejména velká rukavice typu palčáky. 


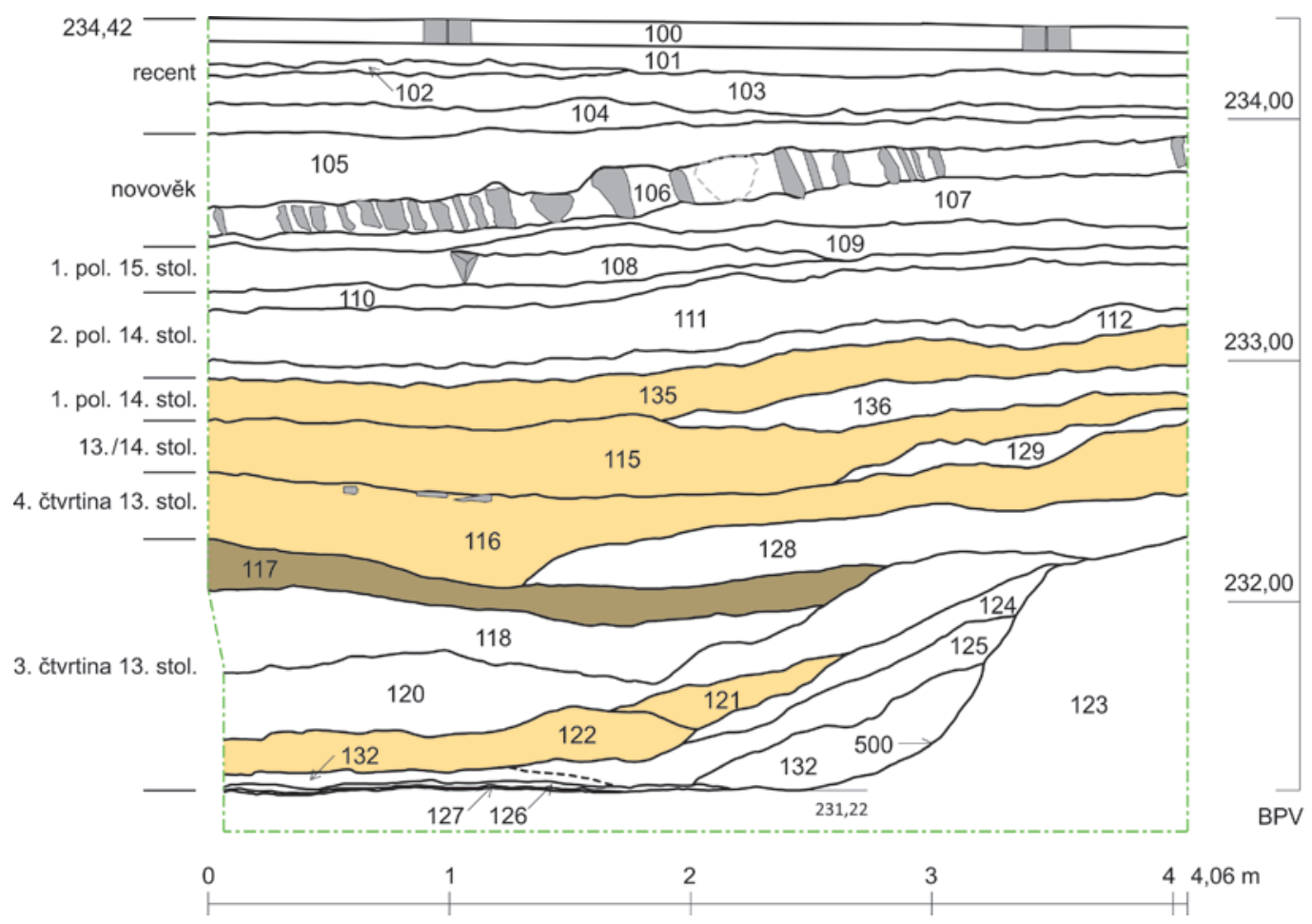

Obr. 2. Litovel, Komenského ulice (akce č. NPU015/03-391), sonda S24/03. Profil P3. Kresba K. Faltýnek, digitalizace J. Grégr.

Fig. 2. Litovel. Komenského Street (fieldwork event No. NPU015/03-391), trench S24/03. Profile P3. Drawing by K. Faltýnek, digitization by J. Grégr.

\subsection{Masarykova ulice (akce č. NPU015/03-391, situace XXXIV)}

\section{Nálezová situace}

Během výstavby kanalizace v roce 2003 byl v Masarykově ulici před č. p. 768 dokumentován profil kanalizační stoky. Výkop sahal do hloubky $2,8 \mathrm{~m}$ od povrchu, aniž by bylo dosaženo podloží. Od hloubky $0,7 \mathrm{~m}$ bylo zachyceno mohutné středověké souvrství z 2. poloviny 13. až 15. století, ležící v hlavní komunikační ose města ve směru sever (Uničov) a jih (Olomouc). Souvrství bylo tvořeno několika jednoduchými dlážděními z posypů říčních oblázků a říčního písku, dále dřevěným hatováním z proutí, jílovitými izolačními vrstvami i odpadními organogenními uloženinami. V hloubkách 0,9 m, 1,6 m a 2,05 m se nacházely úrovně tři kamenných dlažeb. Při bázi výkopu byl dokumentován dřevěný rošt z dubových kulatin. Fragmenty usní byly nalezeny v organogenních uloženinách datovaných do 2. poloviny 13. století.

\section{Charakteristika souboru}

Nevelká kolekce odřezků z dílců a blíže neurčitelného odpadu v celkovém počtu 45 kusů.

\subsection{Masarykova ulice, č. p. 764 ulice (akce č. NPU025/17, sonda S1/17)}

\section{Nálezová situace}

Archeologická sonda byla položena v místech plánované výtahové šachty k hotelu Záložna na parc. č. 210. Sonda měla rozměry 2,5 × 2,6 m. Geologické podloží bylo dosaženo v hloubce 3,2 m pod stávajícím povrchem. Pod recentními uloženinami bylo od úrovně $0,7 \mathrm{~m}$ prozkoumáno typické střredověké souvrství městské parcely ze 2 . poloviny 13 . až 1 . poloviny 15 . století.
Jednalo se o organogenní uloženiny, prokládané zbytky dřevěných konstrukcí i proplétaných plotů a jílovitých izolačních vrstev. Z dřevěných konstrukcí pochází dendrochronologická data z rozmezí let 1324-1341 a 1331-1348 (Rybníček 2020). Fragmenty usní byly získány z organogenních uloženin datovaných do 2. poloviny 13. až 1. poloviny 14. století (Zlámal, Kašpar 2019).

\section{Charakteristika souboru}

Oproti většině předchozích lokalit nepochází zdejší nálezy z uliční sítě, ale z městské parcely. Tvoří je primárně blíže neurčitelné části dílců a odřezky v počtu přibližně 550 kusů, snad odpad z dílny ševce. Identifikovat se podařilo několik vnitřních vyztužovacích dílců obuvi (tzv. opatků) a nekompletní půlpár obuvi složený z části svršku a podešve.

\subsection{Náměstí Přemysla Otakara (akce č. NPU015/03-391, sondy S3/03, S4/03, S10/03, S15/03, situace XVI/2)}

\section{Nálezová situace}

V průběhu výstavby kanalizace $\mathrm{v}$ roce 2003 byly na náměstí Přemysla Otakara položeny čtyři sondy a dokumentována řada terénních situací během výkopu kanalizační stoky (Šlézar, Faltýnek 2004). Nálezy usní byly získány především ze středověkých organogenních uloženin, případně z jednoduchých dláždění v podobě posypů z ř́ícních oblázků a písků.

a) Sonda $\mathrm{S} 3 / 03$ o rozměrech $4 \times 1,2 \mathrm{~m}$ se nacházela $\mathrm{v}$ jihovýchodní části náměstí Přemysla Otakara. Na jílovém podloží v hloubce $2 \mathrm{~m}$ pod současným povrchem náměstí leželo souvrství ze 14. až 15. století, tvořené organogenními odpadními uloženinami, prokládanými vrstvami dláždění z posypů říčních oblázků a izolačními vrstvami jílů. Středověké vrstvy dosahovaly mocnosti 1,6 m (Šlézar, Faltýnek 2004, 204). 
b) Sonda S4/03 o rozměrech 4,2 × 1,1 m byla položena v severovýchodní části náměstí Přemysla Otakara. Štěrkopískové podloží bylo značně nerovné a v jižní polovině sondy se nacházela deprese př́rodního charakteru, vzniklá meandrujícím ramenem Moravy (tzv. Nečíz) v předlokační době. Její dno leželo v hloubce $2,5 \mathrm{~m}$ pod povrchem. Při lokaci města byla tato deprese vyrovnána přemístěným jílem. Následovalo kontinuální horizontální ukládání silně organogenního sídlištního odpadu z 2. poloviny 13. až 15 . století, jednoduchých štěrkopískových dláždění a izolačních jílů. Síla středověkého souvrství byla 1,5 m (Šlézar, Faltýnek 2004, 205).

c) Sonda S10/03 o velikosti $4 \times 1 \mathrm{~m}$ byla situována na jihozápadní straně náměstí Přemysla Otakara, kde bylo výškopisně geologické podloží zaznamenáno nejníže z celého prostoru náměstí. Nacházelo se v hloubce $2,4 \mathrm{~m}$ pod povrchem. Do podloží byl zahlouben dřevěný odvodňovací kanál z doby lokace města v 50. letech 13. století, dendrochronologicky datovaný do doby kolem roku 1256 (Šlézar 2018a, 79). Tento dosud funkční kanál orientovaný ve směru východ-západ, sledovaný v délce $3,5 \mathrm{~m}$, o vnitřní śířce $0,4 \mathrm{~m}$ a hloubce také 0,4 m, sestával z bočních dřevěných fošen s prŕčnými spojkami. Konstrukce byla zajištěna svislými kůly. Povrch kanálu byl překryt deskami a štípami, a vše bylo ještě převrstveno proutěnými hatěmi. Nad kanálem se poté ve 2 . polovině 13 . až 15. století souvisle ukládalo dva metry mocné souvrství organogenních odpadů, izolačních jílů a pět úrovní dláždění v podobě oblázkových posypů (Šlézar, Faltýnek 2004, 205; Šlézar 2018a, 79).

d) Sonda S15/03 o rozsahu 6,5 × 1 m byla umístěná v severozápadní části náměstí Přemysla Otakara. Geologického podloží bylo dosaženo v hloubce $2,5 \mathrm{~m}$ pod povrchem náměstí. Organogenní vrcholně a pozdně středověké vrstvy, prokládané čtyřmi úrovněmi zpevnění povrchu pochůzných terénů tržiště pomocí oblázkových posypů a říčních písků, byly mocné 1,5 m. Dokumentován byl také barokní odpadní kanál a dvě novověké kamenné dlažby (Šlézar, Faltýnek 2005, 205).

e) V linii kanalizace vedené náměstím ve vzdálenosti $9 \mathrm{~m}$ před domem č. p. 793 byla odkryta situace XVI/2. Na jílové podloží v hloubce $2,2 \mathrm{~m}$ pod povrchem nasedalo souvrství středověkých organogenních uloženin a dláždění v podobě oblázkových posypů. Přibližně $0,15 \mathrm{~m}$ nad podložím se v organogenních vrstvách nacházela na ploše o velikosti asi $0,5 \mathrm{~m}^{2}$ kumulace značného množství fragmentů kůží a dílenského odpadu. Několik zlomků keramiky datovalo situaci do 2. poloviny 13. století. Řemeslnické prostředí potvrzuje i nález železného šídla (Šlézar, Faltýnek 2004, 206).

\section{Charakteristika souboru}

Centrální litovelské náměstí, tedy původní středověké tržiště, poskytlo jednu z nejpočetnějších kolekcí v souboru, čítající cca 570 artefaktů, ze kterých bylo možné z funkčního hlediska určit 23 předmětů. Převažovaly nálezy spadající do kategorie obuv (fragmenty z podešví a svršků) a blíže neurčitelné dílce, identifikovány byly části dvou pochev z uloženin 14. století (S10/03 a S15/03), dva fragmenty prosekávaných opasků ze situace datované do 2. poloviny 13. století (situace XVI/2), pouzdro na voskové destičky z vrstvy 14. století (S4/03), nártová část svršku z půlpáru knoflíkové obuvi, další nártová část svršku s ozdobným prošitím špice a tři svrškové dílce z nízce střižené nazouvací obuvi typu „slip-on shoe“ z vrstvy 15. století (S3/03).

\subsection{Náměstí Přemysla Otakara, č. p. 777} (akce č. NPU021/16-391, sonda S1/16)

\section{Nálezová situace}

V roce 2016 proběhl archeologický výzkum v místech plánované výtahové šachty $\mathrm{v}$ jihovýchodní části dvorního traktu domu č. p. 777. Sonda S1/16 měla celkové rozměry $3,2 \times 2 \mathrm{~m}$ a delší stranou byla orientována kolmo na současnou zástavbu. Geologického podloží bylo dosaženo v hloubce 2,4 m pod stávajícím povrchem. V nadloží bylo prozkoumáno souvrství organogenních vrstev z 2. poloviny 13. století, obsahující také nálezy fragmentů kůží. $\mathrm{V}$ rámci souvrství bylo rozlišeno sedm úrovní různých dřevěných konstrukcí. Pravděpodobně se jednalo o pozůstatky podlah hospodářských budov, souvisejících s ustájením dobytka a koní, jak dokládají i otisky zvírecích kopyt a skelet koně nalezený v anatomické poloze na dně zahloubené jámy. Mladší střredověké situace byly zničeny novověkými aktivitami v podobě pěti odpadních jímek a dvou zdí (Faltýnek, Šlézar 2020).

\section{Charakteristika souboru}

Z výzkumu domovní parcely pochází přes 150 blíže neidentifikovatelných kožených fragmentů. Mezi určitelnými nálezy vyniká část dětského půlpáru vyšší knoflíkové obuvi se zdvojenou podešví a jeden zadní vyztužovací dílec obuvi, tzv. opatek.

\subsection{Skládka Nasobůrky - historické jádro Litovle (akce č. NPU015/03-391)}

\section{Nálezová situace}

Hlína z výkopových prací výstavby kanalizace v historickém jádru Litovle byla odvážena na deponii v Nasobůrkách. Zemina pocházející ze středověkých souvrství byla na skládce podrobena průzkumu detektorem kovů značky Fischer model 1270 a podařilo se tak získat i další nekovové nálezy (keramika, dřevěné a kožené artefakty). $V$ řadě případů se povedlo díky informacím od řidičů nákladních aut lokalizovat nalezené artefakty ke konkrétní ulici i popisnému číslu domu.

\section{Charakteristika souboru}

Z prostoru skládky se podařilo zachránit více než 100 kusů rozličného odpadu, podešev, svršek řemínkové obuvi a část opasku či řemene.

\subsection{Revoluční ulice (akce č. NPU015/03-391, sonda S21/03)}

\section{Nálezová situace}

Na Revoluční ulici byla v souvislosti s výstavbou kanalizace na křižovatce ulic Revoluční, Komenského a nám. Svobody provedena v roce 2003 sonda S21/03 o rozměrech $1,8 \times 1,1 \times 4 \mathrm{~m}$ (obr. 3). V hloubce $2,1 \mathrm{~m}$ pod povrchem leželo písčité podloží, do kterého byl ve třech čtvrtinách sondy zahlouben východní okraj mohutného výkopu hlubokého $1 \mathrm{~m}$. Na dně objektu ležela tenká vrstva povodňového kalu, překrytá 0,4 m mocnou organogenní vrstvou s nálezy několika zlomků střešních krytin a zlomků cihel. Až do úrovně okolního podloží byl objekt př̀kryt izolační vrstvou dřevěných hatí a přemístěným podložím. Zřejmě se jednalo o př́íkop z 2. poloviny 13. století, vymezující sakrální areál blízkého kostela sv. Marka, později nahrazený nedalekou ohradní zdí hřbitova. Další pokračování př́íkopu bylo dokumentováno v blízké sondě S7/03. Nad objektem se nacházelo jeden metr mocné středověké souvrství odpadních uloženin 


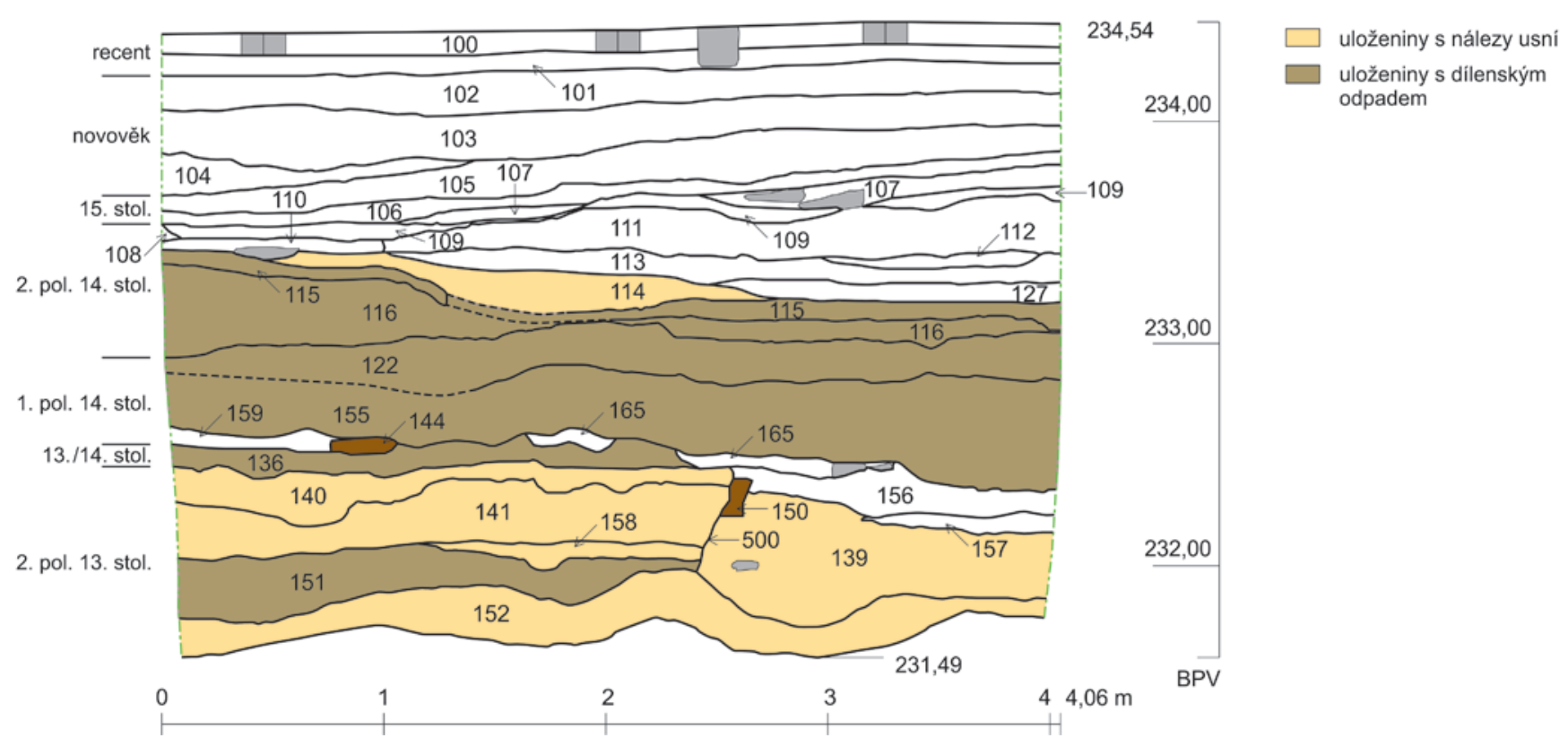

Obr. 3. Litovel, Revoluční ulice (akce č. NPU015/03-391), sonda S21/03. Profil P1. Kresba K. Faltýnek, digitalizace J. Grégr.

Fig. 3. Revoluční Street (fieldwork event No. NPU015/03-391), trench S21/03. Profile P1. Drawing by K. Faltýnek, digitization by J. Grégr.

humózního charakteru. Od 3. čtvrtiny 13. století zde nabývá na intenzitě podíl společenství sešlapávaných rostlin, což indikuje komunikační využívání tohoto prostoru zřejmě související s výstavbou kostela sv. Marka. Následnou intenzivní stavební činnost v okolí sondy ve středověku (přestavby kostela sv. Marka) dokládají zlomky střešních krytin a archeobotanickým rozborem zjištěná vegetace rumišt a smetišt. Novověké vrstvy měly charakter stavebních sutí (Šlézar 2018a, 93).

\section{Charakteristika souboru}

Náznak přítomnosti dílny v podobě částí blíže neurčitelných dílců a odřezků z nich ve vrstvě ze 3 . čtvrtiny 13 . století v počtu téměř 200 kusů (viz obr. 3).

\subsection{Ulice 1. Máje, č. p. 792 (akce č. NPU010/01-391, S1/01)}

\section{Nálezová situace}

Ve dvoře domu č. p. 792 na ulici 1. máje byla v roce 2001 kvůli výstavbě schodiště provedena sonda o velikosti 2,1 × 0,9 m. Geologického podloží bylo dosaženo v hloubce 1,95 m. Do něj se zahluboval objekt hospodářského charakteru. Jednalo se o dubovými fošnami vydřevený chlívek z 3 . čtvrtiny 13 . století s organogenní výplní a nálezy žaludů jako potravy pro vepře. Z objektu také pochází nálezy fragmentů usní. Ze zánikové fáze objektu se zřícenými dřevěnými konstrukcemi pochází i doklady pasířské výroby. Nad objektem se nacházelo souvrství odpadního charakteru z poslední čtvrtiny 13. století až počátku 14. století o mocnosti 1,1 m. Stratigrafický sled vrstev uzavíralo torzo původní cihlové dlažby dvora z 18. století a recentní uloženiny (Faltýnek 2002, 268; Šlézar, Faltýnek 2005; Šlézar 2018a, 83).

\section{Charakteristika souboru}

Početně nejmenší kolekce v souboru tvořená jedním silně poničeným svrškem z neidentifikovatelného typu obuvi a čtyřmi odřezky.

\subsection{Vlašímova ulice (akce č. NPU072/01-391, situace XL/2: před č. p. 773)}

\section{Nálezová situace}

Během výstavby kanalizace v roce 2003 byl na Vlašímově ulici před č. p. 773 dokumentován profil kanalizační stoky. Geologické podloží se nacházelo v hloubce $2,7 \mathrm{~m}$ pod povrchem. Od hloubky 1,6 m se zde objevily odpadní vrstvy organogenního charakteru z 2. poloviny 13. až 14. století, sahající až na intaktní geologické podloží, s nálezy zlomků kůží.

\section{Charakteristika souboru}

Tato ulice skýtá nevelkou kolekci cca 50 artefaktů, mezi kterými se vyskytl jeden blíže neurčitelný svršek obuvi a několik řemínků.

\section{Katalog}

Předkládány katalog zahrnuje výběr toho nejpodstatnějšího z celé množiny litovelských usňových artefaktů. Důraz při výběru byl kladen na variabilitu a maximální možnou výpovědní hodnotu konkrétního předmětu. Jednotlivé artefakty jsou primárně řazeny dle základních funkčních skupin v jedné číselné linii. Až na několik výjimek byla již většina předmětů představena v rámci disertační práce jednoho z autorů (Hoch 2020), avšak u několika málo artefaktů došlo s odstupem času k interpretačnímu zpřesnění. Na tomto místě je také nutné uvést poznámku k možné změně velikosti předmětů (smrštění) vlivem konzervace, která bývá řádově o 1 až 5 \%, v extrémním případě i o více než 10 \%.

\section{č. 1}

funkční skupina: obuv

předmět: nártová, boční a zadní část svršku nízké obuvi upínané páskem (řemínky) přes nárt

místo nálezu: ul. Havlíčkova, sídlištní vrstvy (ulice)

kontext: situace XXXVI/1-2 (sběr), viz kap. 3.2 b 

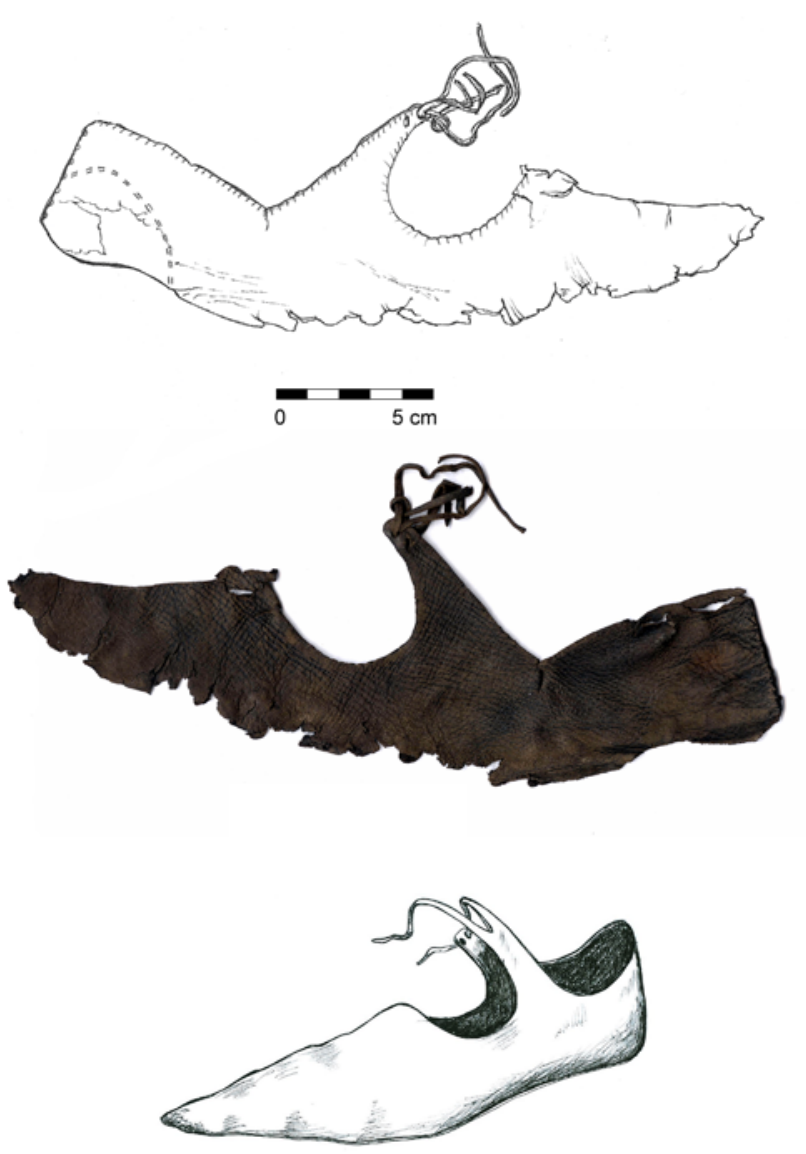

Obr. 4. Nekompletní svrškový dílec nízce střižené obuvi s vykrojeným nártem upínaný k noze pomocí řemínků. Litovel, Havličckova ulice, 14. století. Foto A. Hoch, kresba V. Juráková

Fig. 4. Incomplete upper part of a low-cut shoe with a cut-out instep clamped to the foot with straps. Litovel, Havlíčkova Street, 14th century. Photo by A. Hoch, drawing by V. Juráková.

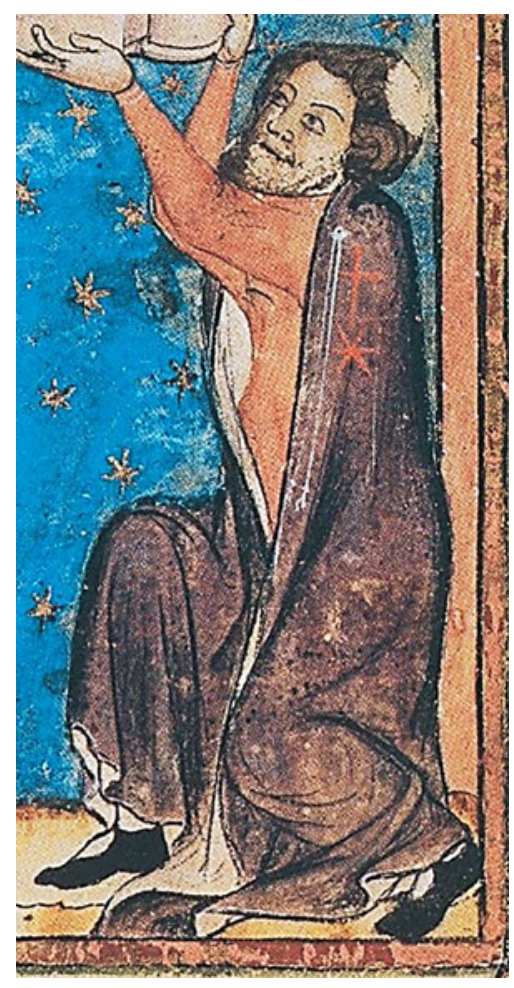

Obr.5. Výřez z Brevíŕe velmistra Lva, r. 1356. Velmistr Konrád má nazut nízce střižený typ obuvi upínaný přes nárt. Převzato $z$ Krása 1990, 124, obr. 65.

Fig. 5. Cut-out from the Breviary of Grandmaster Lev, 1356. Grandmaster Conrad is wearing a low-cut type of shoe clamped over the ankle. Adopted from Krása 1990, 124, Fig. 65. rozměry: $260 \times 45-85 \mathrm{~mm}$

materiál: teletina/hovězina

datace: 14 . století

uložení: Národní památkový ústav, územní odborné pracoviště v Olomouci (dále jen NPÚ, ÚOP v Olomouci)

obr.: $1: 6 ; 4$

popis: část dílce $\mathrm{z}$ nízce střiženého svršku pokrývající nárt, bok a patu. Nárt je vykrojen do oblouku, oblast kotníku do vý-

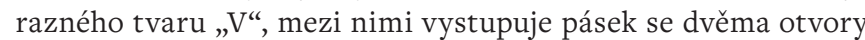
pro tenké usňové zavazovací řemínky, které se ve fragmentech dochovaly také. Horní obvodový okraj je z rubové strany prošit (jednonitový steh rub/hrana), což indikuje př́ítomnost usňové lemůvky, jenž měla na obuvi ozdobnou a zároveň vyztužovací funkci. Na rubové straně se také dochovaly stehy (rub/rub) po našití vyššího obloukovitého opatku. Nález pochází z odpadních a komunikačních vrstev ulice Havlíčkova datovaných rámcově do 13. až 14. století. Tento střih ale není pro 13. století typický, a lze jej poměrně bezpečně zařadit až do století následujícího (více např. Volken 2014, Goubitz et al. 2001). K vidění je také v dobových ikonografických pramenech (obr. 5).

Literatura: Hoch 2020, 88

\section{č. 2}

funkční skupina: obuv

předmět: část dětského půlpáru knoflíkové obuvi (svrškové dílce, zdvojená podešev)

místo nálezu: nám. Přemysla Otakara, č. p. 777, sídlištní vrstvy kontext: 103 (S1/16), viz kap. 3.9

rozměry: svršky $155 \times 110 \mathrm{~mm}, 75 \times 35 \mathrm{~mm}$;

podešve $123 \times 60-38-0 \times 2 \mathrm{~mm}$

materiál: teletina (svršky)

datace: rámcově 14 . až 15. století

uložení: NPÚ, ÚOP v Olomouci

obr.: 1: 7; 6

popis: dva dílce z jednoho svršku, ke kterým pravděpodobně náleží i část podešve. Všechny části byly nalezeny v hnojné vrstvě během výzkumu při stavbě výtahové šachty v č. p. 777 na náměstí Přemysla Otakara (Šlézar et al. 2018, 33; Faltýnek, Šlézar 2020). Větší ze svrškových dílců měl dochované dva otvory pro usňové knoflíky, které byly původně vyztuženy tzv. podkroužkem. Z vyztužovacích dílců byl na půlpáru původně přítomen i nízký opatek, po kterém se obdobně jako v př́ípadě podkroužku, dochovaly pouze stopy po šití. V místě prokrojení nártu byla původně zřejmě našita ozdobná/vyztužovací lemůvka. Ta naopak schází na druhém svrškovém dílci, na který byly našity usňové knoflíky. Dochovaly se po nich dva krátké řezy při okraji, fragment jednoho řemínku a stehy po našití na rubové straně. Obě části svršku byly vykrojeny z teletiny a nastaveny o další dílce, které se již nedochovaly. Spodkové dílce zastupuje mírně asymetricky vykrojená zdvojená podešev, ze které zůstala špice, prstová část i náběh klenku. Zbytek byl odříznut. Zajímavostí je, že byla ke svršku našita méně používaným stehem vedeným ve směru rub/líc, a také její zdvojení, přičemž vnitřní dílec byl našit lícovou stranou vzhůru (což je pro zdvojené podešve typické). Otvor po hřebíčku na rozhraní klenku a prstové části ukazuje na šití pomocí kopyta. I přes absenci ostatních dílců lze půlpár klasifikovat jako vyšší typ dětské obuvi, datovatelný rámcově do 14. století. Literatura: Hoch 2020, 75-76

\section{č. 3}

funkční skupina: obuv

předmět: přibližně polovina dětského půlpáru knoflíkové obuvi (nártová část svršku a prstová část podešve, podkroužek) místo nálezu: ul. Boskovicova, sídlištní vrstvy (ulice) 

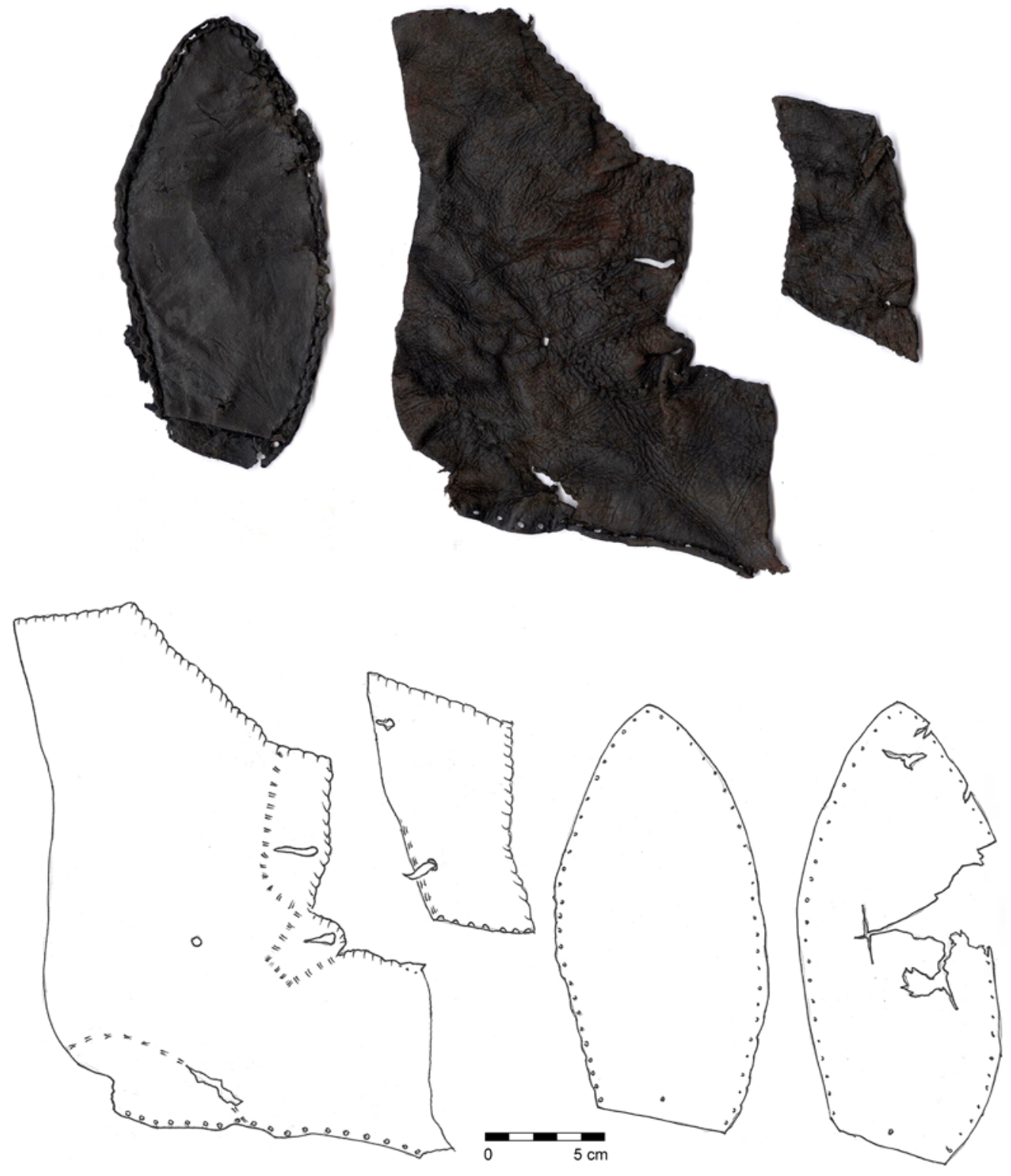

Obr. 6. Část dětského půlpáru knoflíkové obuvi (svrškové dílce, zdvojená podešev). Litovel,

nám. Přemysla Otakara, č. p. 777, rámcově 14. až 15. století. Foto a kresba A. Hoch.

Fig. 6. Part of a child's half-pair of button shoes (upper parts, double sole). Litovel, Přemysl Otakar Square, No. 777, 14th-15th century. Photo and drawing by $A$. Hoch.

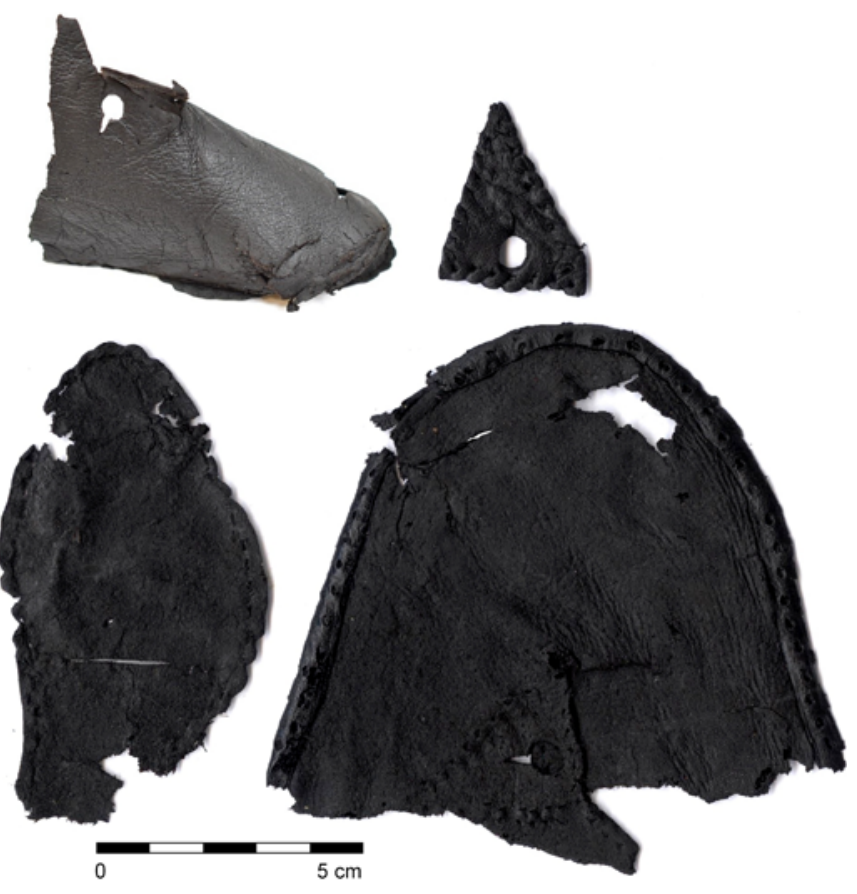

Obr. 7. Polovina dětského půlpáru knoflíkové obuvi (nártová část svršku a prstová část podešve, podkroužek). Litovel, Boskovicova ulice, závěr 14. století. Foto A. Hoch.

Fig. 7. Half of a child's half-pair of button shoes (instep upper- and toe part of the sole, sub-ring). Litovel, Boskovicova Street, end of the 14th century. Photo by A. Hoch. 
kontext: úsek 24,3-25,5 m, hloubka 1-1,2 m, uloženina nečíslována, viz kap. 3.1 a

rozměry: svršek $105 \times 90$, podešev $88 \times 48-0-0 \mathrm{~mm}$, podkroužek $38 \times 34 \times 26 \mathrm{~mm}$

materiál: hovězina (?)

datace: závěr 14. století

uložení: NPÚ, ÚOP v Olomouci

obr.: 1: 8; 7

popis: části svršku a podešve z pravého půlpáru dětské obuvi upínaného k noze pomocí minimálně jednoho usňového knoflíku. Pro jeho provlečení byl ve svršku vyříznut, či spíše proseknut, otvor ve tvaru klíčové stř́lny, vyztužený z rubové strany trojúhelníkovitým podkroužkem, který se dochoval také. Na této straně prokrojení nártu byla navíc patrně našita také lemůvka, čemuž nasvědčují jednonitové stehy při okraji. Zajímavá je špice a nártová část podešve, která byla vykrojena asymetricky a i přes svůj malý rozměr šita na dřevěném kopytu, což dokazuje otvor po přituknutí hřebíčkem. I přes absenci zbytku svršku a zejména usňového knoflíku se lze domnívat, že půlpár náležel do skupiny dětské obuvi zapínané pomocí knoflíků s ocáskem, u kterého O. Goubitz uvádí, že se v 95 \% př́ípadů vyskytuje právě u obuvi dětské velikosti (Goubitz et. al 2001, 201-204).

Literatura: Hoch 2020, 75

\section{č. 4}

funkční skupina: obuv předmět: nártová část svršku obuvi (špice $\mathrm{s} V$ prošitím) místo nálezu: nám. Přemysla Otakara, sídlištní vrstvy

kontext: 112 (S15/03), viz kap. $3.8 \mathrm{~d}$

rozměry: $210 \times 150 \mathrm{~mm}$

materiál: neurčitelné

datace: rámcově 14. až 15 . století

uložení: NPÚ, ÚOP v Olomouci

obr.: 1: $13 ; 8$

popis: zdobený nártový dílec svršku byl patrně součástí půlpáru obuvi upínané k noze bud' pomocí nejméně jednoho usňového knoflíku či řemínku s přezkou (přezkami). Tyto možnosti naznačují stehy po našití usňového řemínku na rubové straně v oblasti prokrojení nártu na jedné straně a po našití vyztužovacího

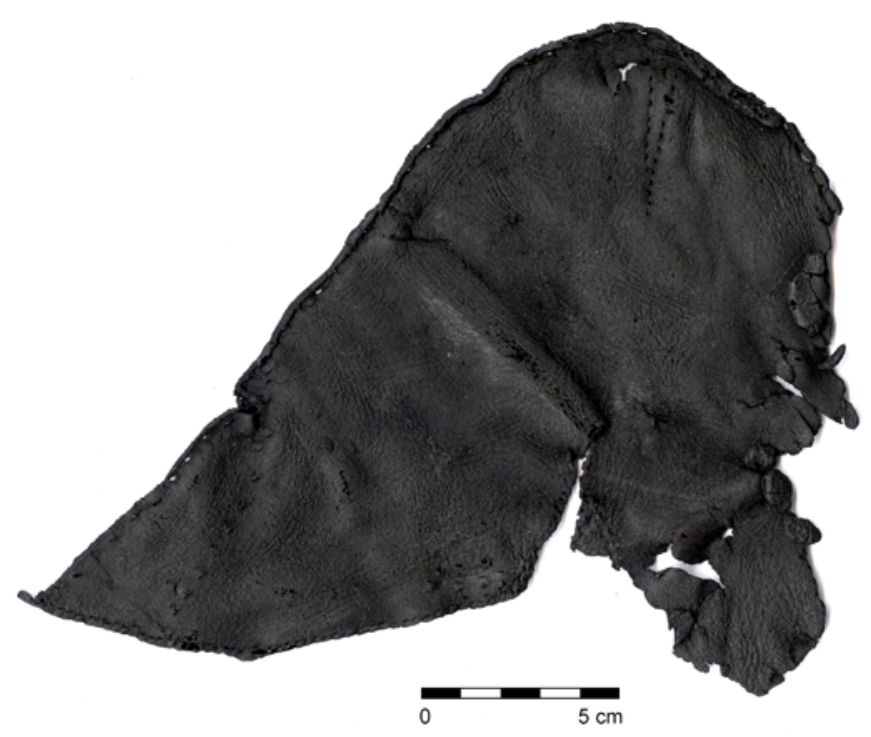

Obr. 8. Špice a nártová část svršku obuvi (špice s ozdobným V prošitím). Litovel, nám. Přemysla Otakara, rámcově 14. až 15. století. Foto A. Hoch. Fig. 8. Toe and upper part of the upper (toe with decorative Vstitching). Litovel, Přemysl Otakar Square, 14th-15th century. Photo by A. Hoch. dílce, tzv. podkroužku, na opačné. Zajímavě je provedeno zdobení špice, a to prošitím do tvaru písmene $\mathrm{V}$, které mohlo být ponecháno pouze takto, nebo zvýrazněno našitím identicky vykrojeného dílce.

Literatura: Hoch 2020, 95

\section{č. 5}

funkční skupina: obuv

předmět: nártová část svršku obuvi, boční/zadní dílce svršku nízké obuvi („slip-on shoe“)

místo nálezu: nám. Přemysla Otakara, sídlištní vrstvy

kontext: 105 (S3/03), viz kap. 3.8 a

rozměry: nárt $130 \times 115 \mathrm{~mm}$, boční $94 \times 33 \mathrm{~mm}$, boční/zadní $64 \times 34 \mathrm{~mm}$

materiál: kozina

datace: rámcově 2 . polovina 15 . století

uložení: NPÚ, ÚOP v Olomouci

obr.: 1: 9; 9

popis: tři dílce svršku vykrojené z koziny byly ke spodkovým dílcům našity stehem vedeným ve směru líc/rub. Nejedná se tedy o tzv. obrácenou obuv, ale o předchůdce obuvi rámové. Tento způsob šití se poprvé objevuje až na sklonku středověku (rámcově od 2. poloviny 15. století), opravdový rozmach zaznamenává až ve století následujícím. Nálezová situace, ze které dílce pochází, byla datována obecně do 15. století, což lze považovat za možné. Obuv byla určena na nohu dětské velikosti a původně zdobena jednoduchým prořezáváním na špici nártu, případně proužkem usně protaženým prořezanými otvory a také obšitím horních okrajů u dvou zadních (či bočních) dílců z vnější lícové strany (což se u běžné středověké obuvi takto nedělalo). Stopy po šití na rubu v oblasti nártu i na jednom z menších dílců naznačují, že vnitřní komfort půlpáru mohla zvyšovat textilní vložka, nebo zde mohl být našit menší vyztužovací dílec. Na základě dostupných analogií se zdá, že nalezené dílce pochází z nízce střižené nazouvací obuvi, nazývané v zahraničí „slip-on shoe“. Literatura: Hoch 2020, 98

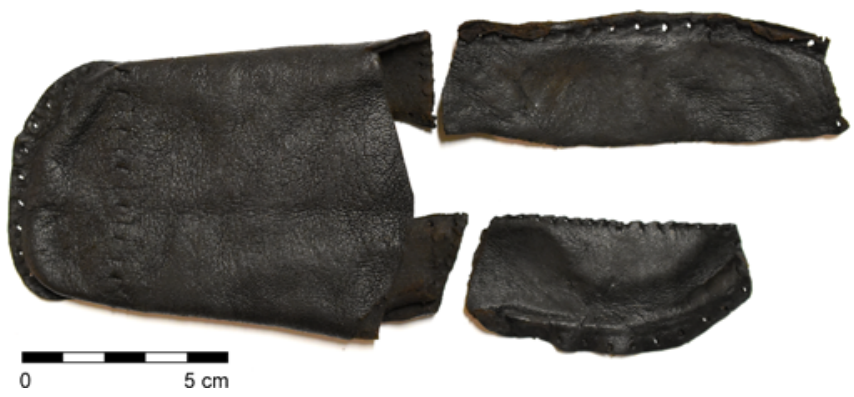

Obr. 9. Nártová část a boční/zadní dílce svršku nízké obuvi („slip-on shoe“). Litovel, nám. Přemysla Otakara, rámcově 2. polovina 15. století. Foto A. Hoch.

Fig. 9. Upper part and side/rear parts of the upper of a low shoe (slip-on shoe). Litovel, Přemysl Otakar Square, around the second half of the 15th century. Photo by A. Hoch.

\section{č. 6}

funkční skupina: pochvy a pouzdra předmět: pochva zdobená řezbou místo nálezu: nám. Přemysla Otakara, sídlištní vrstvy kontext: 113 (S15/03), viz kap. $3.8 \mathrm{~d}$ rozměry: $132 \times 26-23 \mathrm{~mm}$ (v přehnutém stavu) materiál: teletina datace: 14. století 
uložení: NPÚ, ÚOP v Olomouci

obr.: $1: 12 ; 10$

popis: část úzké, pravděpodobně nožové pochvy sešité ve svislé ose zadní strany. Čelní strana je zdobená do povrchu řezaným motivem kř́ízících se linií vytvářejících drobné opakující se kosočtverce.

Literatura: nepublikováno

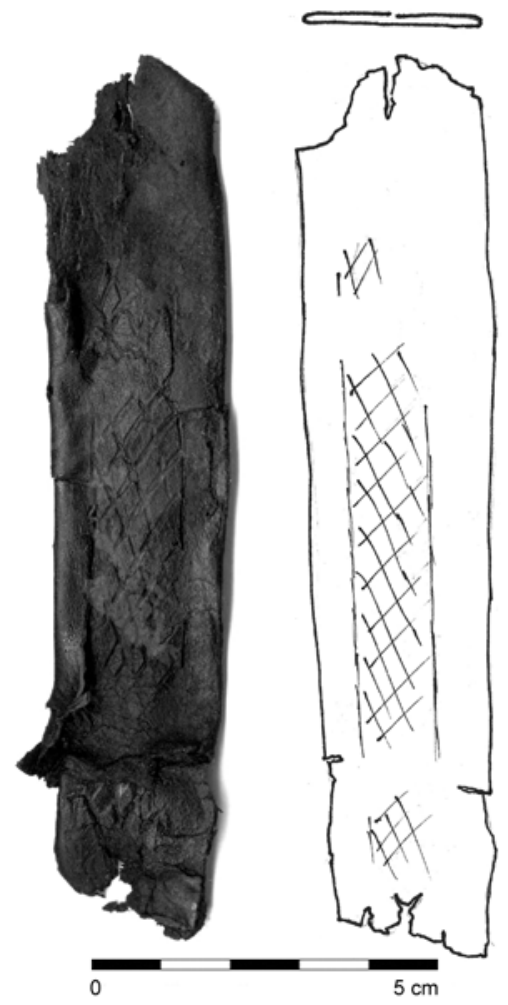

Obr. 10. Část úzké pochvy zdobené řezbou. Litovel, nám. Přemysla Otakara, 14. století. Foto a kresba A. Hoch.

Fig. 10. Part of a narrow sheath decorated with carving. Litovel, Přemysl Otakar Square, 14th century. Photo and drawing by A. Hoch.
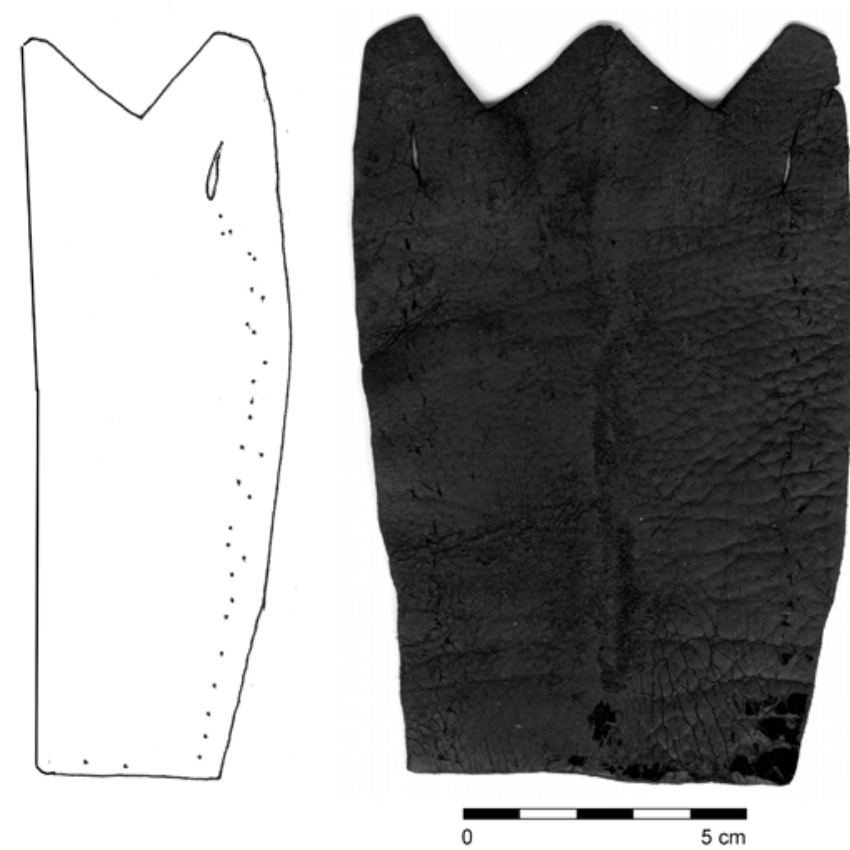

Obr. 11. Pochva. Litovel, nám. Přemysla Otakara, 14. století. Foto a kresba A. Hoch. Fig. 11. Sheath. Litovel, Přemysl Otakar Square, 14th century. Photo and drawing by A. Hoch.

\section{č. 7}

funkční skupina: pochvy a pouzdra

předmět: pochva

místo nálezu: nám. Přemysla Otakara, sídlištní vrstvy

kontext: 118 (S10/03), viz kap. $3.8 \mathrm{c}$

rozměry: $122 \times 41-31 \mathrm{~mm}$ ( $\mathrm{v}$ přehnutém stavu)

materiál: hovězina

datace: 14. století

uložení: NPÚ, ÚOP v Olomouci

obr.: $1: 13 ; 11$

popis: horní část úzké pochvy vyrobené přehnutím materiálu a sešitím na boku. Šití nebylo vedeno při okraji, ale dále od něj, a je velice nepravidelné. Šířka čepele, kterou měla pochva za úkol chránit, se tak pohybovala kolem $25 \mathrm{~mm}$. Ústí pochvy je ozdobně vykrojeno do tvaru písmene $\mathrm{V}$ a mezi ním a okrajem je na každé straně prơ̌íznutý krátký svislý otvor sloužící k zavěšení pochvy na opasek. Předmět celkově působí spíše jako produkt domácké výroby, což konkrétně u pochev není výjimečný jev. literatura: nepublikováno

\section{č. 8}

funkční skupina: pochvy a pouzdra

předmět: pouzdro na voskové psací destičky

místo nálezu: nám. Přemysla Otakara, sídlištní vrstvy

kontext: 110 (S4/03), viz kap. 3.8 b

rozměry: $85 \times 65 \times 30 \mathrm{~mm}$ (ve složeném stavu)

materiál: hovězina

datace: 14 . století

uložení: NPÚ, ÚOP v Olomouci

obr.: 1: 10; 12

popis: spodní úložný díl pouzdra bez víka i bočních řemínků (chybí). Dílec byl vykrojen vcelku, z tuhé hovězí usně silné $3 \mathrm{~mm}$. Otvory pro řemínky, umístěné v párech po obou bočních stranách, jsou silně poničené (potrhané) užíváním. Na nezdobené přední straně jsou patrny dva páry úzkých vně vyboulených otvorů, které sloužily k zasunutí stylu. Pouzdro bylo původně sešito z vnitřní, rubové strany a poté obráceno. $Z$ našeho území pochází mimo Prahu prozatím jediný přesvědčivý nález tohoto typu pouzdra sloužícího k uchovávání a přenosu malých dřevěných destiček potažených voskem, které lze bez nadsázky považovat za diář či poznámkový blok středověkého člověka. Ani v zahraničních souborech se ovšem nejedná o častý nález (srov. např. Goubitz 2009, 88-93).

Literatura: Šlézar, Faltýnek 2004, 207; Hoch 2020, 123-124

\section{č. 9}

funkční skupina: opasky a řemeny

předmět: zdvojený opasek (prosekávaný)

místo nálezu: nám. Přemysla Otakara, sídlištní vrstvy

kontext: situace XVI/2, viz kap. $3.8 \mathrm{e}$

rozměry: $70 \times 20 \mathrm{~mm}$

materiál: neurčitelné

datace: 2. polovina 13. století

uložení: NPÚ, ÚOP v Olomouci

obr.: 1: 11; 13

popis: fragment úzkého zdvojeného opasku s přední stranou zdobenou formou drobných, v krátkých rozestupech šikmo kladených otvorů, tvořících tři hlavní linie - podél okrajů a uprostřed. Na obou poškozených koncích jsou patrné další obdobné otvory kladené do oblouku, přidávající tak k rovným liniím další výzdobný motiv. Tyto motivy mohly být následně ještě prošívány nití, velmi pravděpodobně barevně odlišnou.

Literatura: nepublikováno 


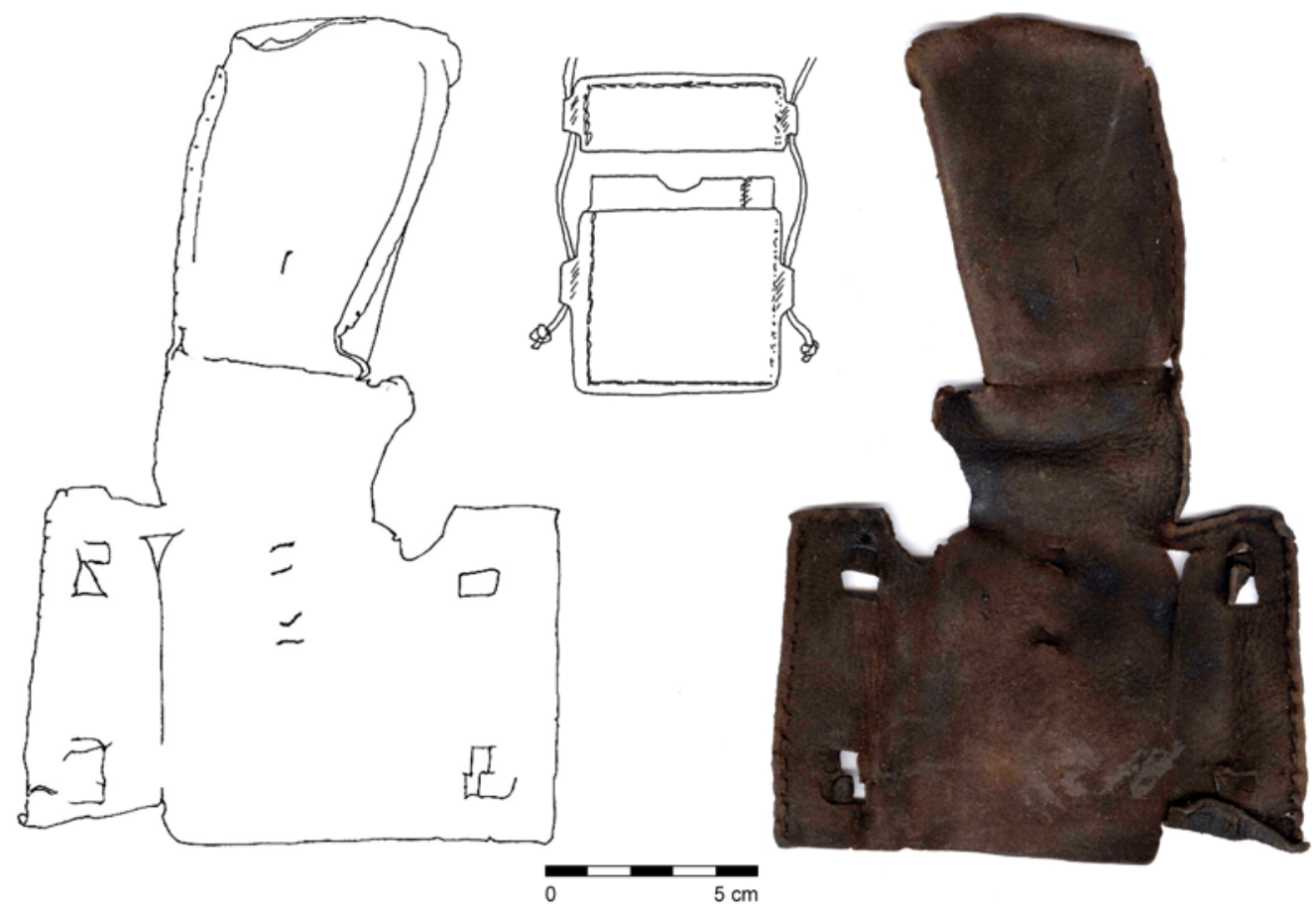

Obr. 12. Pouzdro na voskové psací destičky. Litovel, nám. Přemysla Otakara, 14. století. Foto A. Hoch, kresba V. Juráková, kresebná rekonstrukce pouzdra (uprostřed) převzata z Goubitz 2009.

Fig. 12. Case for wax writing tablets. Litovel, Přemysl Otakar Square, 14th century. Photo by A. Hoch, drawing by V. Juráková, drawing reconstruction (in the middle) adopted from Goubitz 2009.

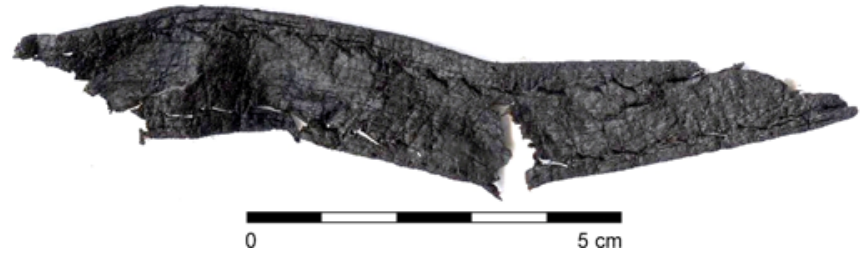

Obr. 13. Fragment zdvojeného prosekávaného opasku. Litovel, nám. Přemysla Otakara, 2. polovina 13. století. Foto a kresba A. Hoch.

Fig. 13. Fragment of a double pierced belt. Litovel, Přemysl Otakar Square, second half of the 13th century. Photo and drawing by A. Hoch.

\section{č. 10}

funkční skupina: opasky a řemeny předmět: opasek (prosekávaný)

místo nálezu: ul. Boskovicova, sídlištní vrstvy

kontext: 170 (S19/03), viz kap. 3.1 b

rozměry: $110 \times 17 \mathrm{~mm}$

materiál: neurčitelné (rozpolcený)

datace: 2. polovina 13. století

uložení: NPÚ, ÚOP v Olomouci

obr.: 1: 11; 14

popis: fragment úzkého rozpolceného opasku s přední stranou zdobenou formou šikmo kladených otvorů, tvořících dvě jednoduché linie podél obou okrajů. Obdobně jako u předchozího
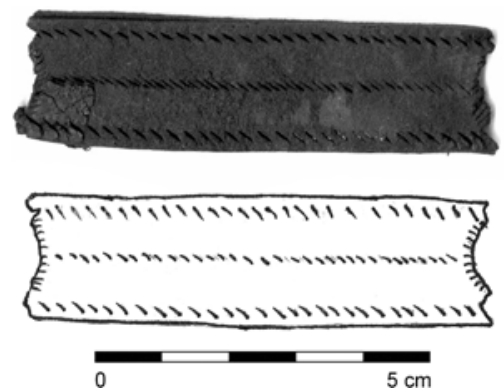

Obr. 14. Fragment prosekávaného opasku. Litovel, nám. Přemysla Otakara, 2. polovina 13. století. Foto A. Hoch. Fig. 14. Fragment of a cut belt. Litovel, Přemysl Otakar Square, second half of the 13th century. Photo by A. Hoch. opasku mohly být tyto otvory následně prošívány nití, což v tomto případě nepřímo dokládají nepatrné otisky nitě v materiálu mezi některými otvory.

Literatura: nepublikováno

\section{č. 11}

funkční skupina: rukavice předmět: rukavice (dvouprstá) místo nálezu: ul. Komenského, sídlištní odpadní vrstvy kontext: 137 (S24/03), viz kap. 3.5 rozměry: rukavice $315 \times 140 \mathrm{~mm}$, palec $105 \times 65 \times 40 \mathrm{~mm}$ materiál: hovězina

datace: 2 . polovina 13 . století uložení: NPÚ, ÚOP v Olomouci

obr.: 1: 14; 15

popis: rozměrná rukavice sešívaná $\mathrm{z}$ více samostatných dílců vykrojených z hověziny. Do současnosti se dochovaly části obou základních polovin, jeden nástavný dílec a dílce z palce. Rukavice byla vykrojena do mírné špice a sešita stehem rub/líc. Pro našití palce byl v materiálu jedné z polovin vykrojen velký trojúhelníkovitý otvor, samotný výkrojek s celou horní (prstovou) částí této poloviny se ovšem nedochval. Celá rukavice i s palcem je nezvykle velká a je pravděpodobné, že mohla mít ještě textilní vložku. Zároveň je ve velice špatném stavu zaviněném jak dekompozicí v půdě, tak opotřebením způsobeným častým užíváním. Rukavice byla určena na levou ruku a jistě nepřekvapí, že nejvíce byla opotřebena právě úchopná část.

Literatura: Hoch 2020, 149

\section{č. 12}

funkční skupina: varia

předmět: obličejová maska (?)

místo nálezu: ul. Jungmannova, sídlištní vrstvy

kontext: 104 (situace V), viz kap. 3.4 a

rozměry: $340 \times 252 \mathrm{~mm}$ (v rozloženém stavu)

materiál: hovězina

datace: 14 . století

uložení: NPÚ, ÚOP v Olomouci 


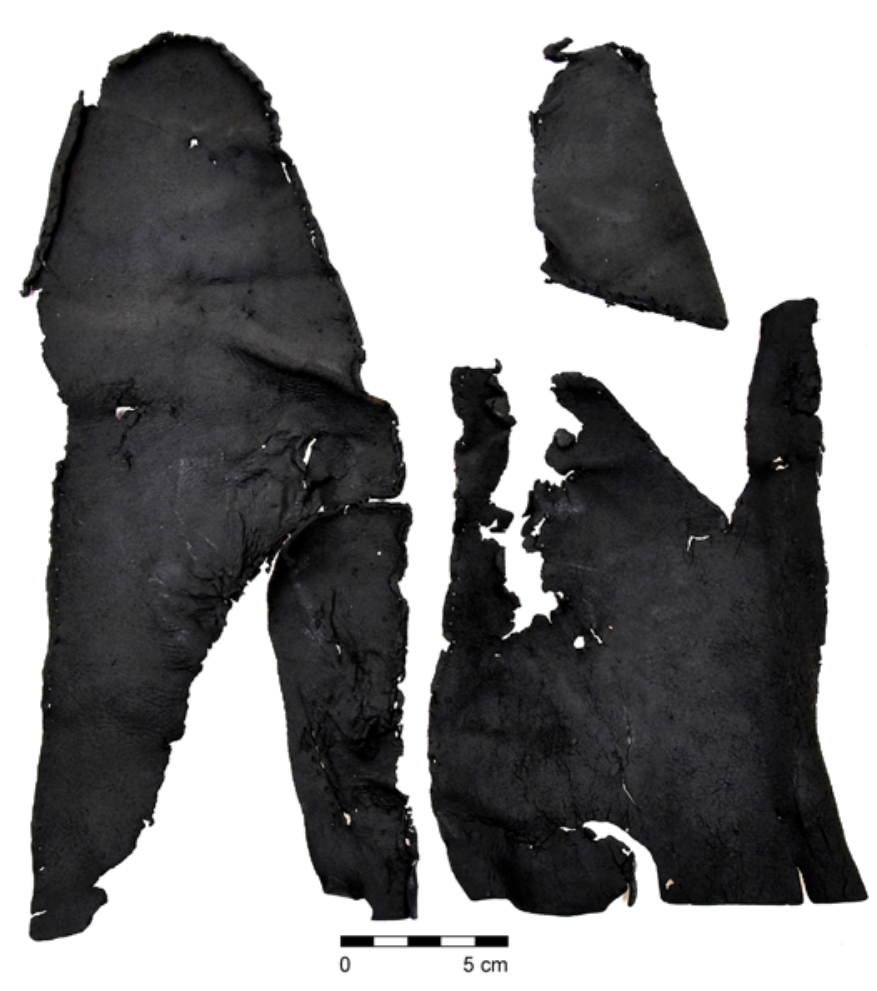

Obr. 15. Rukavice dvouprstá (palčáky). Litovel, Komenského ulice, 2. polovina 13. století. Foto A. Hoch.

Fig. 15. Two-fingered glove (mittens). Litovel, Komenský Street, second half of the 13th century. Photo by A. Hoch.

obr.: $1: 15 ; 16$

popis: předmět, vykrojený z jednoho kusu tuhé, až $2 \mathrm{~mm}$ silné hověziny, na první pohled působí jako půlpár obuvi, jímž ovšem zřejmě není. Artefakt je po celém obvodu prošitý různými typy stehů, přičemž některé strany viditelně pasují k sobě. Po jejich opětovném přiložení a prostorovém natvarování dostane předmět tvar obličejové masky, kterou bylo možné nasadit na hlavu podobně jako přílbu. Nepravidelně vykrojený otvor v předpokládané obličejové části umožňoval v obou případech poměrně bezproblémové pozorování okolí. Druhá, poškozená a evidentně opravovaná polovina obličejové části má tento „oční“ otvor také, pouze je více poničen. Míra poškození této oblasti znemožňuje ŕíci, zda byly v materiálu přítomny i otvory pro nos a ústa. Nezdá se to ovšem pravděpodobné, i když náznak původní přítomnosti krátkých, úzkých úst zde existuje. V ploše materiálu jsou dále patrné stehy (rub/líc), nápadně kopírující linii lidského obličeje. V teoretické zadní části jsou nedaleko okraje na obou stranách úzké párové otvory známé např. ze svršků obuvi. Pokud by i tyto sloužily (obdobně jako na obuvi) k provlečení řemínků, bylo by jimi možné masku po nasazení na obličej přivázat (přitáhnout) těsněji k hlavě. Celý artefakt lze tedy s maximální možnou mírou opatrnosti interpretovat jako obličejovou masku, která by se v tomto stavu po sešití v jeden celek obtížně nasazovala na hlavu dospělé osobě. V současném rozměru by se stěží vešel na hlavu i dítěti staršímu cca tř́ let. Nelze ovšem vyloučit, že předmět byl původně větší, resp. že v zadní části schází rozšiřující nástavný klín. Rozměry usně mohla ovlivnit i recentní konzervace, která nezřídka způsobí smrštění od $1 \%$ do $5 \%$, v extrémních případech až do $20 \%$. Předmět by také mohl být užíván pouze symbolicky, např. nasazením na pevnější podklad (např. kůl).

Literatura: Hoch 2020, 155-156

\section{Vyhodnocení nálezového celku (diskuze)}

V obecné rovině je možné konstatovat, že kompletní litovelský soubor představuje relativně typickou kolekci vrcholně a pozdně středověkých usňových artefaktů. V jednotlivých kategoriích, dělených dle současné metody do skupin na základě původní funkce, zcela dominuje blíže neurčitelný odpad, záměrně deponovaný do volných prostranství (plocha náměstí, uliční sít, nezastavěné části domovních parcel apod.). Tato situace má paralely na jiných lokalitách (napřr. Hoch 2015; Hoch, Bartík 2019; Figura 2019 aj.). Ve skupině nálezů identifikovatelných z hlediska původní funkce převažuje obuv, což je opět situace zcela běžná na mnoha dalších lokalitách u nás (srov. Hoch, Dejmal 2013; Hoch, Staněk 2015; Hoch 2015, 2018; Figura 2019; Hoch 2020) i v zahraničí (např. Schnack 1994; Kowalska 2013; Wywrot-Wyszkowska 2008 aj.). V menší míře následují oděvní doplňky (opasky, rukavice) a předměty denní potřeby (pochvy a pouzdra). Zcela unikátním nálezem, mimo tyto běžné kategorie, je bezesporu obličejová maska, vyzvednutá z oblázkové dlažby datované do 14. století, která patří k nejpozoruhodnějším usňovým artefaktům vůbec. Obličejové masky se ve středověkých usňových souborech vyskytují až na výjimky zcela vzácně. Početné různotvaré formy pochází pouze z ruského Novgorodu (Kollekcii onlajn 2018; Rybina 1992, 181-182), ojediněle byly zachyceny v německých Brémách (13./14. století), holandském Kampenu (16./17. století, obr. 17) či lotyšské Rize (13. století; více Rech 2004, 322-323). Rozměry většiny z nich se ovšem pohybují mezi 150 až $250 \mathrm{~mm}$, a bývají tak interpretovány jako dětské hračky. Jsou však jednoduššího střihu a připomínají spíše současné škrabošky, kdežto litovelskou masku by bylo možné nasadit na hlavu jako přílbu. Ačkoliv zjevně není zcela kompletní, lze na základě dochovaných rozměrů odhadovat, že po opětovném sešití by ji mohlo nosit malé dítě, maximálně předškolního věku. Obecně sloužily masky ve středověku a raném novověku $\mathrm{k}$ rozličným účelům. Mohly být např. součástí pouličních zábav, průvodů, oslav, rejů a her, kterých se během roku konalo před i za městskými hradbami mnoho (cf. Verdon 2003; Zíbrt 2006; Dvořáčková-Malá, Zelenka a kol. 2014 aj.), nebo se mohlo jednat o ryze žertovné předměty. Užívány mohly být také při práci s ohněm u pecí a výhní, jak tomu naznačuje vyobrazení ve slavné knize Georgia Agricoly Dvanáct knih o hornictví a hutnictví (Agricola 1556), kde si muži u tavících pecí záměrně chrání obličej. Pokud tedy litovelský nález opravdu sloužil svému předpokládanému účelu, tedy během slavností, ceremonií či k pouhému dětskému strašení, otevírá nám pomyslné okno do jinak obtížně postihnutelné oblasti života středověkého člověka, do světa her, zábav a rituálů (např. maškarní reje apod.).

Vzácně nalézanými předměty jsou také pouzdra, v př́ípadě litovelského nálezu konkrétně na psací destičky. Blok dvou a více (obvykle 3 až 8) malých dřevěných desek potažených voskem (rozměry zahraničních nálezů oscilují mezi 3-6 × 6-10 cm, Goubitz 2009, 87), které mohly být na jedné straně spojeny (a bylo jimi tak možné listovat), sloužil jako středověký zápisník, do kterého se záznamy ryly pomocí kovového, příp. kostěného stylu. Přítomnost stylu lze na pouzdrech doložit i nepřímo, a to pomocí úzkých, horizontálně kladených otvorů, sloužících k jeho zasunutí (obr. 18). Pouzdra však mohla mít i jiné způsoby užití (na hřebeny, jehly, kalamáře, brýle, nůžky, knihy či jako škapulíre, více např. Goubitz 2009, 87-106). Z našeho prostředí byla dosud prokazatelně identifikována pouze v Praze, odkud pochází i předměty vysoké estetické hodnoty zdobené na čelní straně lisovanými motivy (Figura 2019, 129-130). Litovelské pouzdro lze považovat za jednoduchý, nezdobený typ a jistě nepřekvapí, že pochází z plochy centrálního náměstí, které sloužilo mimo jiné jako hlavní místo obchodu. Dokládají to i nálezy 

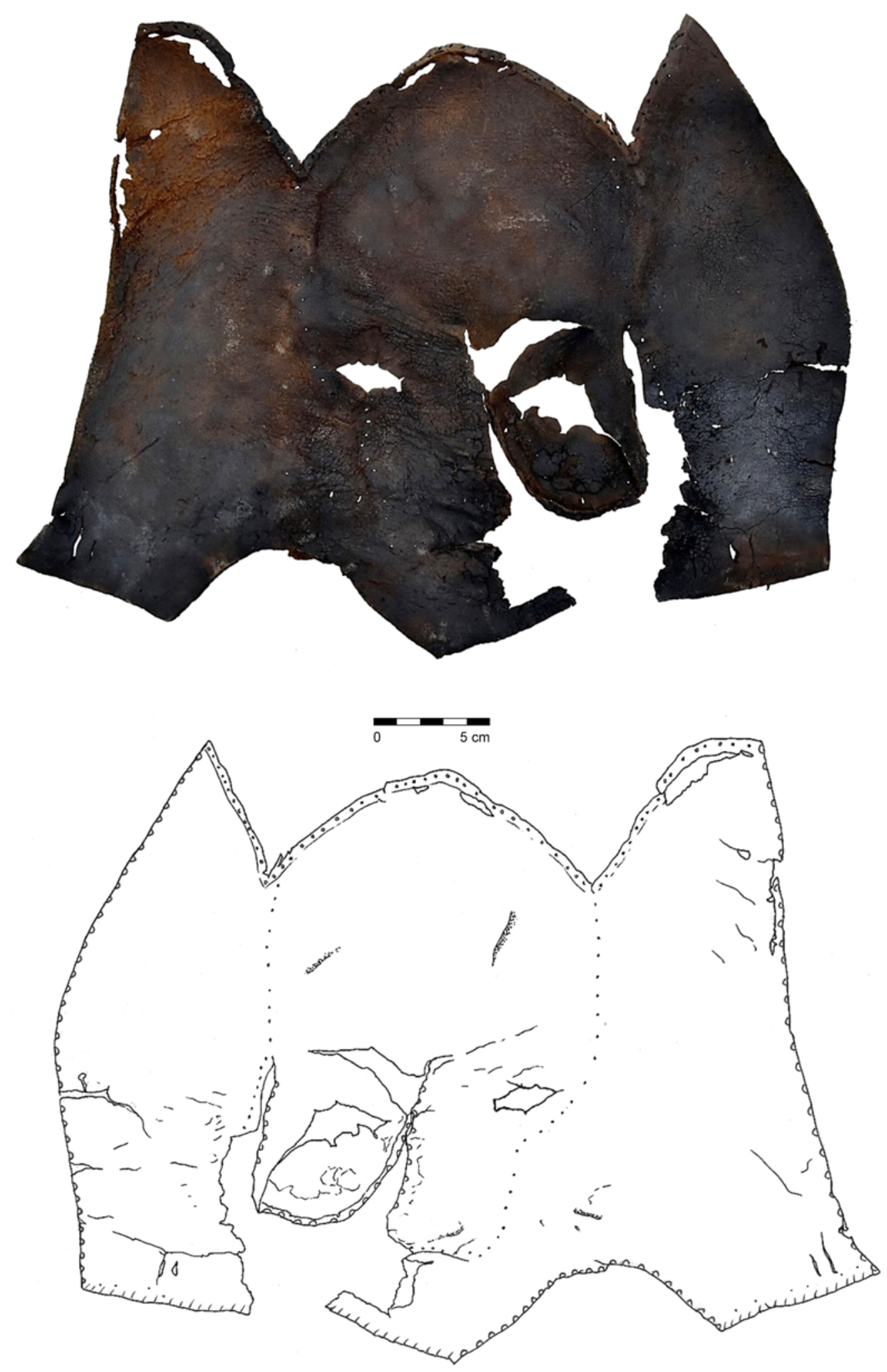

Obr. 16. Obličejová maska (?). Litovel, Jungmanova ulice, 14. století. Foto A. Hoch, kresba V. Juráková.

Fig. 16. Face mask (?). Litovel, Jungmanova Street, 14th century. Photo by $A$. Hoch, drawing by V. Juráková.

čtyř železných stylů z období 13. až 15. století z historického jádra Litovle. Přímo z náměstí Přemysla Otakara pochází nálezy dvou stylů. První je datován do přelomu 13. a 14. století a druhý do 15. století (Šlézar 2018a, 101).

Rídce, avšak pravidelně se v souborech usňových artefaktů objevují také rukavice typu palčáky, které lze považovat spíše za cestovní a pracovní oděvní doplněk (obr. 19). V základním tvaru se nijak neliší od soudobých rukavic, odlišná je ovšem konstrukce palce. Palec byl na rukavice našíván samostatně, a pro tento účel byl v materiálu vyř́íznut trojúhelníkovitý otvor, jehož nejkratší strana zůstávala pevně spojená s rukavicí. Zbylá část průřezem vytvořeného „výkrojku“ pak tvořila součást externě našívaného dílu palce. Trojúhelníkovitý otvor v těle rukavice i výkrojek byly vždy prošity podél okraje, a jsou tak výborným identifikátorem rukavice, nebot se na žádném jiném výrobku nevyskytuje a nelze jej s ničím zaměnit (Hoch 2020, 149). Analogie $\mathrm{k}$ těmto rukavicím pochází z mnoha míst Evropy, nejlépe zpracované pochází např. z Holandska (Willemsen 2015). V našem prostředí byl doposud početnější soubor zaznamenán v Uherském Hradišti (Hoch, Bartík 2019, 95-97; Hoch 2020, 149-150).

K poměrně běžným nálezům řadíme fragmenty dvou opasků zdobených prosekáváním, které mohlo být ještě doplněno pro 


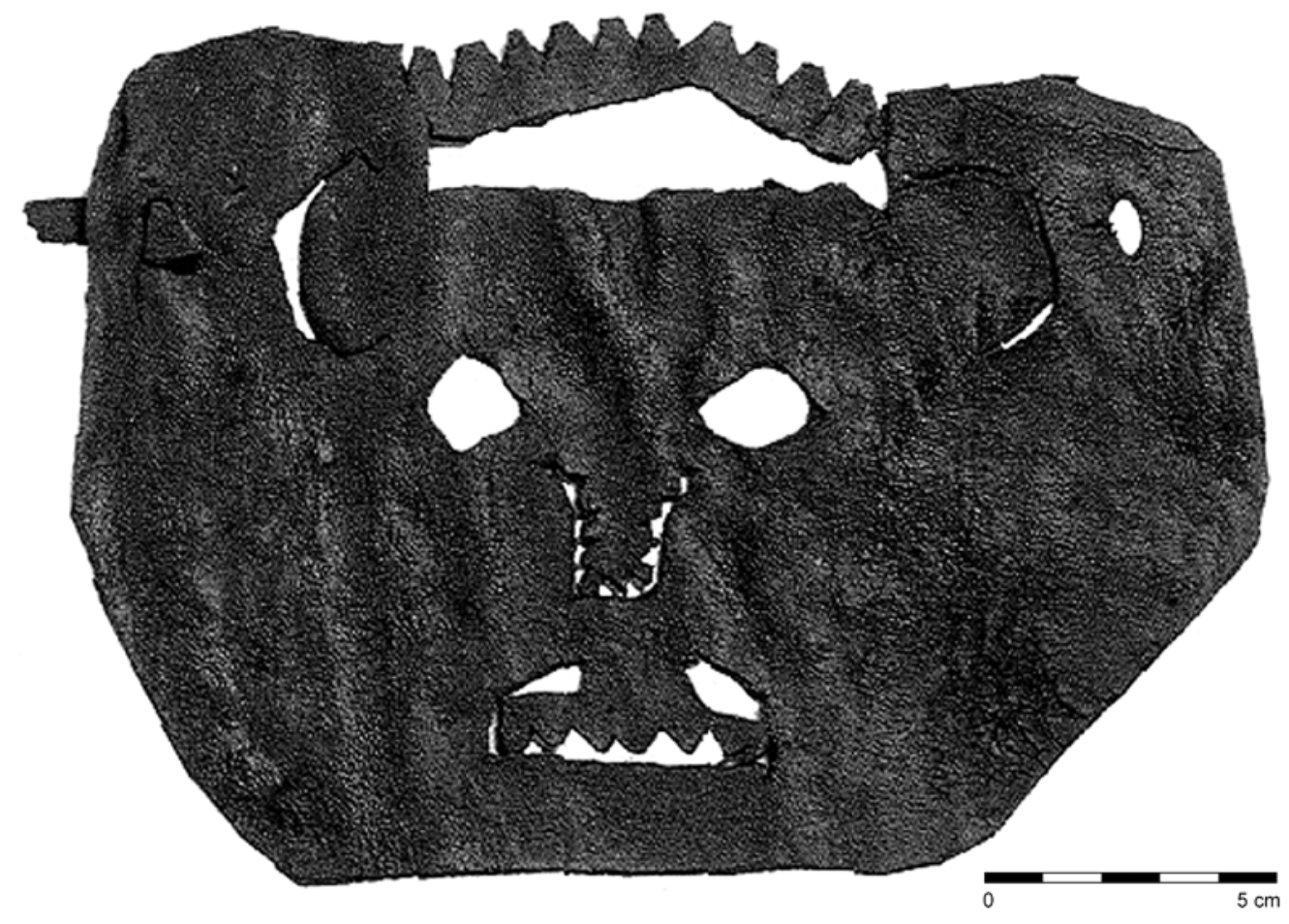

Obr. 17. Usňová maska z Kampenu, 16./17. století. Převzato z Rech 2004, 323.

Fig. 17. Leather mask from Kampen, 16th/17th century. Adopted from Rech 2004, 323. větší pevnost a zdobnost prošíváním. V našem prostředí se takové prošití nedochovalo, jelikož k němu byla zjevně používána nit̉ rostlinného původu (degraduje), známe ho však ze zahraničí (např. Londýna), odkud je doloženo prošití hedvábím. Takovéto prošití mělo nejen dekorační funkci, ale zároveň zabraňovalo natahování materiálu (Mould et al. 2003, 3392-3397; Egan, Pritchard 2002, 38-39). V Anglii tyto opasky proto také neoznačují jako „prosekávané“, ale „prošívané“. Z typologického hlediska se jedná o nejrozšířenější formy opasků oblíbené zejména ve 13. až v 1. polovině 14. století minimálně v celé střední, severní a západní Evropě (např. Schnack 1998, 44-58). Z našeho prostředí pochází nejpočetnější soubor např. z Hradce Králové (Hoch 2020, katalog, č. 99, 102-105).

Bohužel mnoho nelze říci o dvou pochvách náležících pravděpodobně $\mathrm{k}$ nožům. U obou zaujme alespoň skutečnost, že je každá jiným způsobem zdobná. První, přibližně středový úsek

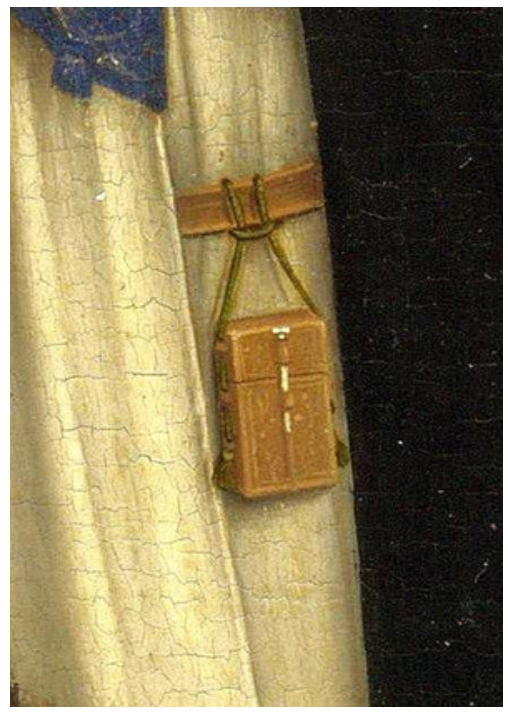

Obr. 18. Pouzdro na voskove psací destičky zavěšené na opasek. Na přední straně zastrčen malý stylus. Výřez z obrazu Pieta, r. 1465 (The National Gallery). Fig. 18. Wax writing tablet case hanging on a belt. A small stylus tucked into the front. Cut-out from a painting of the Pieta, 1465 (The National Gallery). úzké pochvy je v přední části zdoben u tohoto typu předmětů zřídka užívanou technikou řezby, tedy nařezáváním svrchní lícové vrstvy. Za výzdobný motiv bylo zvoleno jednoduché šikmé křížení čar, vytvářející tak drobné káry. Druhá pochva je zdobena „zubovitým“ vykrojením horního okraje (ústí). Tato pochva zaujme i způsobem spojení (resp. prošití), které je poměrně nepravidelné, a působí jako domácký výrobek, což není u tohoto typu předmětů výjimečný jev (např. Hoch, Bartík 2019, 94).

Poslední doloženou a nejpočetnější kategorií je obuv. $V$ předchozí části textu bylo uvedeno, že drtivou část předmětů ve všech litovelských souborech tvoří dnes již blíže neurčitelný primární a sekundární odpad, případně odpad z dílen. Je nanejvýš pravděpodobné, a celková analýza kompletního nálezového celku tuto domněnku potvrzuje, že se jedná primárně o dnes již zcela zničené části (dílce) obuvi. Středověká obuv náležela ke spotřebnímu zboží s rychlou mírou opotřebení a fluktuace, zároveň však patřila $\mathrm{k}$ nepostradatelným oděvním doplňkům s výrazným módním aspektem. Proto je také nejčastěji nacházeným typem usňových předmětů, se značným typologicko-chronologickým potenciálem. Její fragmentárnost je ovšem natolik značná, že ve většině případů nelze určit $\mathrm{z}$ jakého dílce, natož konkrétního typu obuvi, pochází. Tento fakt je dán zejména místem uložení, což jsou v př́ípadě Litovle převážně veřejná prostranství, tedy místa s přímým působením př́rodních živlů a vysokou frekvencí pohybu lidí a zvířat. Usňové artefakty z takovýchto míst, na rozdíl od nálezů z jímek a studní, bývají téměř pravidelně v silně fragmentárním stavu a počet přesně determinovatelných předmětů bývá nízký. Obdobná situace není neobvyklá a analogická zjištění známe z Uherského Hradiště (Hoch, Bartík 2019, 99) či Prahy (Figura 2019, 125-128).

Přes výše popsané komplikace se i v litovelském souboru našly určitelné typy obuvi. Z hlediska rozměrů převažují dětské velikosti, jev mající často analogie i v jiných souborech (Hoch 2020, katalog, č. 1-4, 14, 17-22, 25). Již jsme zmínili, že středověká obuv byla náchylná na rychlé obnošení, a nutnost opravy/výměny tak nastávala poměrně brzy. U dětí je však tento fakt umocněn skutečností, že jejich chodidlo stále roste 


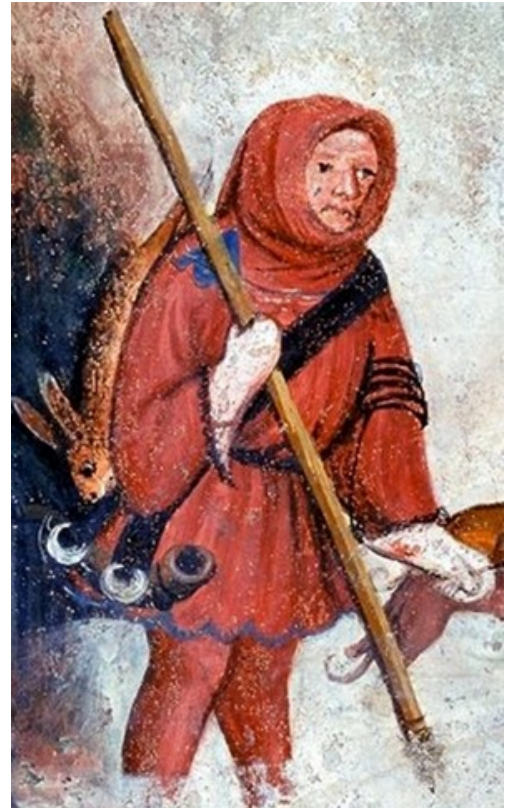

Obr. 19. Lovec ve dvouprstých rukavicích typu palčáky, severní Itálie, konec 14. století. Výřez z fresky z cyklu Ciclo dei Mesi, Trento. Převzato z Schneider 2012, 164.

Fig. 19. A hunter in twofingered mittens, northern Italy, late 14th century. Cutout from a fresco from the Ciclo dei Mesi cycle, Trento. Adopted from Schneider 2012, 164.

a obuv je nutné měnit častěji. Pěkným př́íkladem dětské obuvi je nekompletní půlpár z ulice Boskovicova, který se hlásí do skupiny obuvi zapínané pomocí usňových knoflíků s tzv. ocáskem, u které O. Goubitz uvádí, že se v 95 \% případů vyskytuje právě u obuvi dětské velikosti (Goubitz 2001, 201-204). Výrazný typologicko-chronologický potenciál má i část svršku z nízce stř̌iženého půlpáru se šněrováním na nártu, typický představitel módy 14. století s analogiemi jinde v Evropě (více Volken 2014, 157-159; Goubitz 2001, 167-171). Z této skupiny vyzdvihněme ještě nekompletní nález půlpáru nízké nazouvací obuvi označované v zahraničí jako „slip on shoe“. Tato obuv je obecně datována do konce 15 . až průběhu 16. století, analogie opět nalezneme na mnoha místech Evropy, nám nejblíže např. v polské Varšavě (Blusiewicz 2009, 62-63).

Pětice míst z historického jádra Litovle (viz kap. 3.2, 3.5, 3.7, $3.8,3.11)$ poskytla také doklady práce řemeslníků a řemeslné výroby v podobě většího množství výrobního odpadu. Jedná o stovky až tisíce převážně malých až drobných odřezků z nových

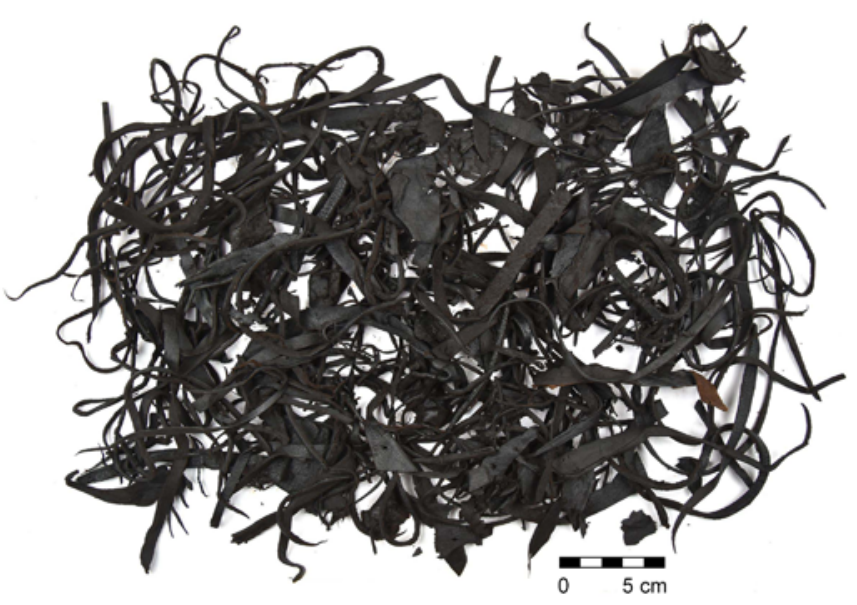

Obr. 20. Část výrobního odpadu z Masarykovy ulice, Litovel, dokládající př́tomnost řemesIné dílny. Foto A. Hoch.

Fig. 20. Part of the production waste from Masaryk Street, showing the presence of a craft workshop. Photo by A. Hoch. či již evidentně použitých usní (obr. 20). Díky přítomnosti tohoto recyklátů je možné usuzovat, že odpad pochází z dílen ševců, př́ípadně ševců-vetešníků. Až na nález železného šídla z náměstí Přemysla Otakara, nejsou uvažované dílny doprovázeny dalšími dílčími nálezy (např. řemeslné nástroje, ševcovská kopyta), které by tuto domněnku potvrdily. Tyto nálezy nejsou známé ani z ostatních výzkumů v historickém jádru Litovle a také samotná nálezová místa nelze spojit s žádnými písemnými prameny. I přes tento fakt je možné takovýto nadměrný výskyt odpadního materiálu vcelku bezpečně považovat za blízký doklad řemeslné výroby. Analogickou situaci známe např. z Prahy (Figura 2019, 128) či Českých Budějovic (Hoch 2018, 259-260). Oproti dobře vyhodnotitelným usňovým nálezům z odpadních jímek, kde se v mnoha př́padech dají spolehlivě využít i četné písemné prameny, jako např. z Plzně (Orna, Dudková 2020), je vyhodnocení nálezů z veřejných ploch měst mnohem problematičtější. Dílenský odpad se v terénních situacích nacházel jak v kumulacích na poměrně malých plochách o obsahu kolem $0,5 \mathrm{~m}^{2}$ (Havličkova ulice, náměstí Přemysla Otakara; trrírozměrné objemy nezjištěny), tak byl i rovnoměrně rozmístěn v rámci jednotlivých uloženin (Masarykova ulice a Revoluční ulice). Dokonce nacházíme i stejnoměrné rozložení dílenského odpadu v několika vrstvách nad sebou, tvořícího mocné souvrství kolem jednoho metru (Komenského ulice), což koresponduje s již dříve konstatovaným poměrně rychlým procesem tvorby antropogenních vrstev na veřejných plochách města Litovle (Šlézar, Faltýnek 2004, 207; Šlézar 2018a, 83). Toto souvrství ze 14. století se utvářelo přibližně 100 let a svědčí o dlouhodobém nepřetržitém provozu dílny ševce-vetešníka v okolí nálezu (srov. obr. 2). Ševcovská dílna v blízkosti sondy na Komenského ulici však existovala po nějakou dobu již ve 2. polovině 13. století, jak dokládají nálezy odpadu v jedné z uloženin takto datovaného souvrství.

\section{Závěr}

Předkládaná kolekce usňových artefaktů z historického jádra města Litovle náleží z hlediska množství $\mathrm{k}$ nejpočetnějším souborům v rámci České republiky. Přesto obsahuje v drtivé většině blíže neurčitelný odpad s mizivým množstvím přesněji determinovatelných předmětů. Tuto skutečnost ještě umocnil fakt, že veškeré nalezené předměty pochází z uliční sítě, případně domovních parcel, kde byly po svém deponování dále vystaveny lidské a zvírecí činnosti, rozmarům počasí apod. Kvalita dochování předmětů z tohoto prostředí pak vždy zaostává za nálezy z výplní zahloubených objektů, zejména odpadních jímek a studní, což lze doložit analogiemi z mnoha míst u nás i v zahraničí. Nálezová místa bohatá na rozličné formy odpadu ovšem mohou přinést i doklady jinak obtížně identifikovatelných řemeslných dílen. To se v prrípadě Litovle podařilo prokazatelně na třech místech. Jedná se zřejmě o dílny ševců, př́ípadně ševců-vetešníků. Z nalezených artefaktů vyniká nález pravděpodobné dětské obličejové masky, nemající doposud v našem prostředí přímé analogie. K vzácným nálezům se řadí i pouzdro na psací destičky či nízká nazouvací obuv ilustrující módu konce středověku a nastupující éry renesance.

\section{Poděkování}

Práce vznikla v rámci výzkumného dílčího cíle oblasti Archeologie I.1. Zpracování a vyhodnocení záchranných archeologických výzkumů NPÚ na vybraných nemovitých kulturních památkách, městských rezervacích, zónách a územích České republiky s dosud nechráněným archeologickým potenciálem [Záchranný archeologický výzkum], financovaného z institucionální podpory Ministerstva kultury na dlouhodobý koncepční rozvoj (IP DKRVO). 


\section{Literatura}

Agricola, G. 1556: De re metallica libri XII. Basileae. Dostupné také z: https://archive.org/details/georgiiagricolae00agri/page/n3/ mode/2up.

Bezděčka, J. 1993: Dějiny města Litovle od počátku až do února 1948. I-IV. Uničov. Rkp. Uloženo: fond Vědecké knihovny v Olomouci, sign. B II 858.570/ 1-4.

Blusiewitz, K. 2009: Obuwie warszawskie z XIV-XVIII wieku. In: W. Pela (ed.): Archeologia dawnej Warszawy, tom 1. Warszawa: Muzeum Historyczne m. st. Warszawy, 11-224.

Čermák, M. 2002: Olomoucká řemesla a obchod v minulosti. Olomouc: Memoria.

Dvořáčková-Malá, D., Zelenka, J. a kol. 2014: Přemyslovský dvi̊r. Život knižat, králů a rytírư ve středověku. Praha: Nakladatelství Lidové noviny.

Egan, G., Pritchard, F. 2002: Dress accessories c. 1150-c. 1450. Medieval Finds from Excavations in London 3. London: Museum of London.

Faltýnek, K. 2002: Litovel (okr. Olomouc). Přehled výzkumů 43, 267-270. Dostupné také z: https://arub.cz/wp-content/ uploads/07_pv_43_2001_stredovek_a_novovek.pdf.

Faltýnek, K. 2019: Výprava po Litovli, In: K. Faltýnek, M. Golec, M. Hlava, L. Hlubek, P. Kalábková, Z. Mírová, P. Šlézar, R. Urválek: Výpravy za litovelskou archeologií. Litovel: Muzejní společnost Litovelska, 120-137.

Faltýnek, K., Šlézar, P. 2006: Archeologické výzkumy sakrálních staveb v Litovli. Archaeologia historica 31, 303-322. Dostupné také z: http://hdl.handle.net/11222.digilib/140675.

Faltýnek, K., Šlézar, P. 2016: Litovel (okr. Olomouc). Přehled výzkumů 57(2), 280-281. Dostupné také z: https://www.arub.cz/ prehled-vydanych-cisel/PV-57_2_stredovek-a-novovek.pdf.

Faltýnek, K., Šlézar, P. 2020: Litovel (okr. Olomouc). Přehled výzkumů 61(2), 164-165. Dostupné také z: http://pv.arub.avcr.cz/61_2_06.pdf.

Figura, J. 2019: Středověké technologie zpracování usní. Archeologia technica 31, 125-131. Dostupné také z: https://bit.ly/3rtI7y5.

Goubitz, O., Driel-Murray, C. van, Groenman-van Waateringe, W. 2001: Stepping through Time. Archaeological Footwear from Prehistoric Times until 1800. Zwolle: Stichting Promotie Archeologie.

Goubitz, O. 2009: Purses in Pieces. Archaeological finds of late medieval and 16th-century leather purses, pouches, bags and cases in the Netherlands. Zwolle: Stichting Promotie Archeologie.

Grolich, V. 1971: Cechy v Litovli. Manufaktura novozámecká. Litovel. Rkp. Uloženo: Muzeum Litovel.

Hoch, A. 2015: Středověká kožedělná produkce z Jihlavy v odrazu hmotné kultury. Archeologické výzkumy na Vysočině 6/2015, 101-134.

Hoch, A. 2018: Středověká kožedělná produkce z Českých Budějovic v odrazu hmotné kultury. Archeologické výzkumy v jižních Čechách 31, 253-277.

Hoch, A. 2020: Kožedělná výroba v českých zemích ve středověku. Rkp. disertační práce. Masarykova univerzita. Filozofická fakulta. Ústav archeologie a muzeologie Masarykovy univerzity. Uloženo: Ústřední knihovna Filozofické fakulty Masarykovy univerzity. Dostupné také z: https://is.muni.cz/th/lch5n/.

Hoch, A., Bartík, J. 2019: Středověké usňové artefakty z vybraných lokalit v Uherském Hradišti (Stará radnice, Reduta, Františkánská). Slovácko: společenskovědní sborník pro moravsko-slovenské pomezí LIX, 87-104.

Hoch, A., Dejmal, M. 2013: Kožené artefakty z hradu ve Veselí nad Moravou. Archaeologia historica 38(2), 653-671. Dostupné také z: http://hdl.handle.net/11222.digilib/128345.

Hoch, A., Staněk, P. 2015: Kožené artefakty z České ulice v Brně. Archaeologia historica 40(2), 913-927. Dostupné také z: http://hdl.handle.net/11222.digilib/134214.
Kalábková, P. 2018: Dějiny archeologického výzkumu. In: K. Konečný (red.): Litovel - velké dějiny města. 1. Od nejstarších dob do roku 1918. Olomouc: Univerzita Palackého v Olomouci, 22-34.

Kollekcii onlain 2018: Eksponaty. Koža. In: Novgorodskij muzej-zapovednik. [online]. (c2018 Novgorodskij gosudarstvennyj ob“edunjënnyj muzej-zapovednik. [cit. 2021-12-10]. Dostupné z: https://bit.ly/31N1RBS.

Kowalska, A. B. 2013: Wytwórczość skórzana w późnosredniowiecznej Dzielnicy Chyzyńskiej w Szczecinie. Szczecin: Instytut Archeologii i Etnologii PAN.

Krása, J. 1990: České iluminované rukopisy 13.-16. století. Praha: Odeon.

Lošták, J. 1976: Litovelská městská kniha soudní a pamětní 1359-1577. Rkp. diplomové práce. Masarykova univerzita. Filozofická fakulta. Uloženo: Ústřední knihovna Filozofické fakulty Masarykovy univerzity.

Mould, Q., Carlisle, I., Cameron, E., 2003: Craft, Industry and Everyday Life: Leather and Leatherworking in Anglo-Scandinavian and Medieval York. York: Council for British Archaeology.

Orna, J., Dudková, V. 2020: Poznání kožedělné produkce královského města Plzně v období vrcholného stř̌edověku a raného novověku na základě nálezů kožených artefaktů z odpadních jímek. Archaeologia historica 45(1), 483-503. Dostupné také z: http://hdl.handle.net/11222.digilib/142977.

Rech, M. 2004: Gefundene Vergangenheit - Archäologie des Mittelalters in Bremen. Mit besonderer Berücksichtigung von Riga. Begleitpublikation zur gleichnamigen Ausstellung im Focke-Museum/ Bremer Landesmuseum vom 19. November 2003 bis 28. März 2004. Bonn: Habelt.

Rybina, E. A. 1992: Leather Articles. In: M. Brisbane (ed.): The Archeology of Novgorod, Russia. Recent Results from the Town and its Hinterland. Lincoln: Society for medieval archaeology.

Rybníček, M. 2020: Litovel - Záložna. Dendrochronologická laboratoř Lesnické a dřevařské fakulty Mendelovy univerzity. Rkp. závěrečné zprávy. Uloženo: Národní památkový ústav, územní odborné pracoviště v Olomouci.

Schnack, K. 1994: Mittelalterliche Lederfunde aus Konztanz. Stuttgart: Kommissionsverlag, K. Theiss.

Schnack, K. 1998: Mittelalterliche Lederfunde aus Schleswig: Futterale, Riemen, Taschen und andere Objekte: Ausgrabung Schild 1971-1975. Neüminster: Wachholtz.

Schneider, R. 2012: Alltag im Mittelalter. Das Leben in Deutschland vor 1000 Jahren. München: Bassermann.

Šlézar, P. 2005: Litovel (okr. Olomouc). Přehled výzkumů 46, 288-290. Dostupné také z: https://www.arub.cz/wp-content/uploads/ pv_46_2004_stredovek_a_novovek.pdf.

Šlézar, P. 2018a: Archeologie středověkého města. In: K. Konečný (red.): Litovel - velké dějiny města. 1. Od nejstarších dob do roku 1918. Olomouc: Univerzita Palackého v Olomouci, 68-103.

Šlézar, P. 2018b: Fortifikační systém města Litovle ve středověku. Vlastivědný věstník moravský LXX(3), 253-268.

Šlézar, P., Faltýnek, K. 2004: Litovel (okr. Olomouc). Přehled výzkumů 45, 204-207. Dostupné také z: https://www.arub.cz/ wp-content/uploads/pv_45_2003_stredovek_a_novovek.pdf.

Šlézar, P., Faltýnek. K. 2005: Litovel, 1. máje čp. 792. Rkp. nálezové zprávy M-TX-200602589. [cit. 2021-10-03]. Uloženo: Archiv nálezových zpráv Archeologického ústavu AV ČR, Brno. Dostupné také z: Digitální archiv: https://digiarchiv.aiscr.cz/ id/M-TX-200602589.

Šlézar, P., Faltýnek, K. Grégr, J. 2018: Archeologický atlas MPZ Litovel [online]. Národní památkový ústav, Metainformační systém, (c) 2018 [cit. 2021-09-07]. Dostupné z: https://iispp.npu.cz/mis_public/documentDetail.htm?id=1026533. 
The National Gallery: Pietà [online]. (C) 2016-2021 The National Gallery. [cit. 2021-10-03]. Dostupné z: https://www.nationalgallery.org.uk/paintings/ probably-by-the-workshop-of-rogier-van-der-weyden-pieta.

Verdon, J. 2003: Volný čas ve středověku. Praha: Vyšehrad.

Volken, M. 2014: Archaeological Footwear: Development of shoe patterns and styles from Prehistory still the 1600s. Assen: Stichting Promotie Archeologie.

Vrbová, J. 2001: Olomouc, Litovel. Závěrečná zpráva. Dendrochronologická laboratoř AƯ AV ČR Brno. Rkp. závěrečné zprávy. Uloženo: Národní památkový ústav, územní odborné pracoviště v Olomouci.

Willemsen, A. 2015: Honderden...Van hand tot hand. Handschoenen en wanten in de Nederlanden voor 1700. Zwolle: Spa uitgevers.

Winter, Z. 1906: Dějiny řemesel a obchodu v Čechách v 14. a 15. století. Praha: Česká akademie císaře Františka Josefa pro vědy, slovesnost a umění.

Wywrot-Wyszkowska, B. 2008: Skórnictwo w lokacyjnym Kolobrzegu. XIII-XV wiek. Sczcecin: Instytut Archeologii i Etnologii PAN.

Zíbrt, Č. 2006: Veselé chvíle v životě lidu českého. Praha: Vyšehrad.

Zlámal, T., Kašpar, P. 2019: Litovel (okr. Olomouc). Přrehled výzkumů 60(2), 281-282. Dostupné také z: https://www.arub.cz/ prehled-vydanych-cisel/pv_60_2__stredovek_novovek.pdf.

\section{Summary}

The former royal town of Litovel, situated northwest of the Upper Moravian Valley, is among the best archaeologically investigated Moravian towns. To date, 12 major and 70 smaller archaeological research activities have been carried out in $\mathrm{Li}^{-}$ tovel, which are recorded in detail through the information and mapping system, the Archaeological Atlas of the Litovel MPZ (Šlézar et al. 2018). The most extensive excavation to date took place during the construction of the sewer system in 2003, which affected approximately $75 \%$ of the street network of the historic core of the town.

Between 1997 and 2017, a large collection of leather fragments from the second half of the 13th to 15 th century was obtained from archaeological rescue excavations carried out in the historic centre of Litovel. The collection comes from thirteen sites in the historic urban core of Litovel and comprises more than 3,500 artefacts. It is not possible to determine the exact number, as a significant part is in a highly fragmentary state. Only a few dozen artefacts have been determined in terms of their original function although only a fraction could be assigned to specific types. All the remaining objects can be described as primary to secondary waste, among which manufacturing waste was often present, indicating the proximity of a workshop. All artefacts were first classified according to the place of discovery, and then according to contemporary methodology into functional groups (shoes, sheaths and holsters, belts and straps, gloves, miscellaneous). The selected objects with the greatest predictive value were catalogued and described in detail.

In general terms, it can be stated that the complete Litovel assemblage represents a relatively typical collection of high and late medieval leather artefacts. The individual categories, divided based on the current method into groups according to the original function, are dominated by indeterminate waste, deliberately deposited in open spaces (area of the square, street network, unbuilt house plots, etc.). This situation has parallels in other locations (e.g. Hoch 2015; Hoch, Bartík 2019; Figura 2019, etc.).

The group of finds identifiable in terms of their original function is dominated by footwear, a situation quite common in many sites in the Czech Republic (cf. Hoch, Dejmal 2013; Hoch, Staněk
2015, 2018; Figura 2019; Hoch 2020) and abroad (e.g. Kowalska 2010; Wywrot-Wyszkowska 2008; Schnack 1994, etc.). This is followed to a lesser extent by clothing accessories (belts, gloves) and everyday objects (sheaths and holsters). A unique find is a face mask recovered from a pebble pavement dated to the 14th century. Face masks are rare in medieval leather sets. Numerous finds come from Novgorod, Russia (Kollekcii onlain 2018; Rybina 1992, 181-182), and have been sporadically recorded in Bremen, Germany (13th/14th century), Kampen, Netherlands (16th/17th century), and Riga, Latvia (13th century; for more, see Rech 2004, 322-323). However, the dimensions of most of these range between 150 and $250 \mathrm{~mm}$ and are thus interpreted as children's toys. However, they have a simpler design and resemble more contemporary scarves, whereas the Litovel mask could be worn on the head as a helmet. Although it is not completely whole, it can be estimated, based on the preserved dimensions, that it could have been worn by a young child, at most of preschool age.

Rarely found objects also include pouches; in the case of the Litovel find, specifically for writing tablets. The Litovel pouch can be considered as a simple, undecorated type. It comes from the area of the central square, which was the main place of trade. This is evidenced by the discovery of four iron styluses from the 13th-15th century from the historic core of Litovel. Two styluses were found directly in Přemysl Otakar Square. The first is dated to the end of the 13th and early 14th century and the second to the 15th century (Šlézar 2018a, 101). Mittens, which can be considered more of a travel and work clothing accessory, also appear in small quantities but regularly in leather artefact assemblages. Analogies to Litovel gloves come from many places in Europe, the best-crafted ones coming from, for example, the Netherlands (Willemsen 2015). Within our milieu, the most numerous set has so far been recorded in Uherské Hradiště (Hoch, Bartík 2019, 95-97; Hoch 2020, 149-150). Among the relatively common finds are fragments of two belts with pierced decoration, which may have been supplemented for greater strength and ornamentation by stitching. Such stitching has not survived in our environment, as it was apparently done by a thread of organic origin (it degrades) although it is known from abroad (e.g. London), where silk stitching is documented. Such stitching not only had a decorative function but also prevented the material from stretching (Mould et al. 2003, 3392-3397; Egan, Pritchard 2002, 38-39).

Not much can be said about the two sheaths that probably belong to knives. What is interesting about both of these is that each is decorated differently. The first, approximately central section of the narrow scabbard is decorated on the front with a carving technique rarely used on this type of object, i.e. incising the upper face layer. A simple oblique crossing of lines was chosen as the decorative motif, thus forming a tiny, checked pattern. The second scabbard is decorated with a tooth-like cutting of the upper edge. This scabbard also impresses by how the parts are joined (or stitched), which is rather irregular and looks like a homemade product, which is not an exceptional phenomenon for this type of artefact (e.g. Hoch, Bartík 2019, 94).

The last documented and most numerous category is footwear. In terms of dimensions, children's sizes predominate in the Litovel collection. A good example of children's shoes is an incomplete half pair from Boskovicova Street, belonging to the group of shoes fastened with leather buttons with a so-called tail. Another valuable find is part of the upper of a low-cut halfpair with lacing at the upper, a typical example of 14th-century fashion with analogues elsewhere in Europe (for more, see Volken 2014, 157-159; Goubitz 167-171). Of this group, mention 
can also be made of the incomplete discovery of a half-pair of low slip-on shoes, referred to abroad as a "slip-on shoe". This shoe is generally dated to the late 15 th or during the 16th century; analogues can again be found in many places in Europe, the closest to us, for example, in Warsaw, Poland (Blusiewicz 2009, 62-63).

Five sites from the historic core of Litovel (see sections 3.2, $3.5,3.7,3.8,3.11$ ) also provided evidence of artisan work and craft production in the form of large quantities of production waste. These are hundreds to thousands of mostly small to tiny offcuts from new or apparently already used leather. The presence of this recyclate makes it possible to infer that the waste came from the workshops of shoemakers or cobblers. Apart from the discovery of an iron awl from Přemysl Otakar Square, the workshops under consideration are not accompanied by other partial finds (e.g. craft tools, shoemakers' hooves) that would confirm this assumption. These findings are not known from other excavations in the historical core of Litovel either. Nor can the finds themselves be linked to any written sources. Despite this, such an excessive occurrence of waste material can be considered as close evidence of craft production.

During the excavations, workshop waste was found in clusters in relatively small areas of around $0.5 \mathrm{~m} 2$ (Havlíčkova Street, Přemysl Otakar Square, three-dimensional volumes not detected) and was evenly distributed within individual deposits (Masarykova Street and Revoluční Street). We also found an even distribution of workshop waste in several layers on top of each other, forming a powerful layer of about one metre (Komenský Street), which corresponds with the previously noted relatively rapid process of anthropogenic layer formation in the public areas of Litovel (Šlézar, Faltýnek 2004, 207; Šlézar 2018a, 83). This 14th-century stratum took approximately 100 years to form and testifies to the long-term continuous operation of a shoemaker's workshop in the vicinity of the find. However, a shoemaker's workshop in the vicinity of the Komenský Street test pit existed for some time in the second half of the 13th century, as evidenced by the discovery of waste in one of the deposits of such a dated stratum.

The collection of leather artefacts from the historic core of Litovel is one of the largest collections in the Czech Republic in terms of quantity. Nevertheless, it mainly contains unidentifiable waste with a scarcity of more precisely identifiable objects. All the objects found come from the street network and squares, or house plots, where they were further exposed to human and animal activity, the vagaries of the weather, etc. The quality of the preservation of objects from this environment always lags behind that of finds from the fills of buried objects, especially sewage pits and wells, which can be documented by analogies from many sites in this country and abroad. However, sites rich in various forms of waste may also yield evidence of otherwise difficult to identify craft workshops. In the case of Litovel, this has been demonstrated at three sites. These appear to be shoemaker or cobbler workshops. Among the artefacts found, the discovery of a probable children's face mask, which has no direct analogues in our milieu to date, stands out. Rare finds include a writing tablet case and low slip-on shoes illustrating the fashion of the Late Middle Ages and the emerging Renaissance era.

\section{Kontakty}

\section{Aleš Hoch}

Muzeum Vysočiny Jihlava, p. o.

Masarykovo náměstí 55

CZ-586 01 Jihlava

hoch@muzeum.ji.cz

\section{Pavel Šlézar}

Národní památkový ústav, územní odborné pracoviště v Olomouci Horní náměstí 25

CZ-779 00 Olomouc

slezar.pavel@npu.cz 